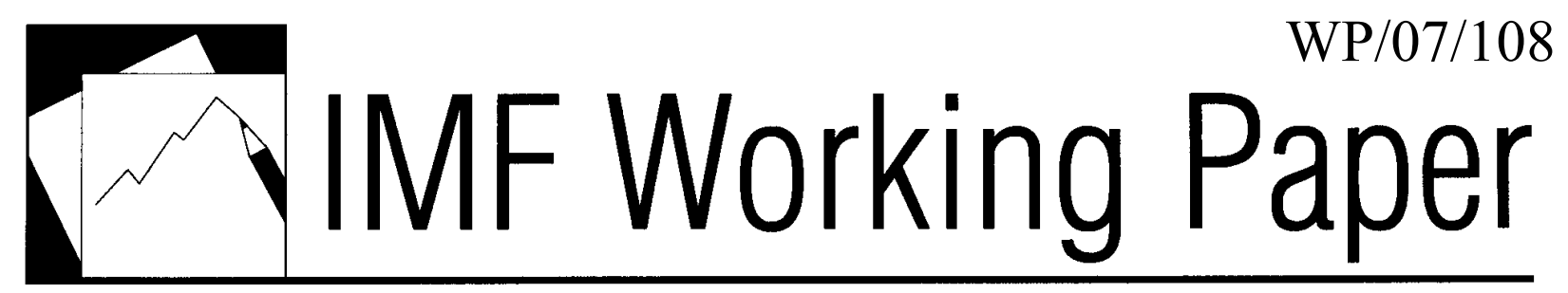

\title{
Pension Reform and Macroeconomic Stability in Latin America
}

Jorge Roldos 



\title{
IMF Working Paper
}

IMF Institute

Pension Reform and Macroeconomic Stability in Latin America ${ }^{1}$

Prepared by Jorge Roldos

May 2007

\begin{abstract}

\section{This Working Paper should not be reported as representing the views of the IMF.} The views expressed in this Working Paper are those of the author(s) and do not necessarily represent those of the IMF or IMF policy. Working Papers describe research in progress by the author(s) and are published to elicit comments and to further debate.

This paper reviews macroeconomic aspects of pension reforms in Latin America, focusing on financial market stability and fiscal sustainability. Concentration of pension fund portfolios in government bonds remains high, and the lack of new investment alternatives has distorted asset prices. Countries have gradually liberalized investments abroad, but remain wary of the impact on foreign currency markets. The fiscal costs of the transition to funded systems have been higher than expected, and have contributed to high debt levels. The paper highlights the importance of coordinating changes in portfolio limits with debt management policies and measures to develop securities markets.
\end{abstract}

JEL Classification Numbers:

Keywords:

Author's E-Mail Address: JRoldos@imf.org

\footnotetext{
${ }^{1}$ This paper was written as part of my TAP at WHD. Thanks are due to WHD for its hospitality and to HRD for financial support. Special thanks also to Roberto Benelli, Ravi Balakrishnan, Stephanie Eble, Chris FaulknerMacDonagh, Roberto Garcia-Saltos, Gil Mehrez, Alejandro Lopez Mejia, Wendell Samuel, Calvin Schnure, and Esteban Vesperoni, for invaluable input on the specifics of country reforms, and to Caroline Atkinson, Charles Collyns, Jose Fajgenbaum, Chris Towe, Tim Lane, and Ben Clements for useful comments at different stages of the project. Zlatko Nikolski provided excellent research assistance.
} 


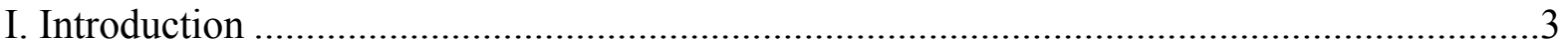

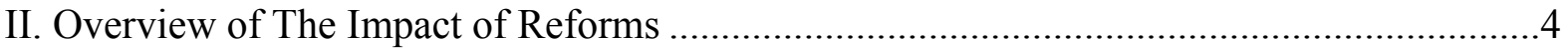

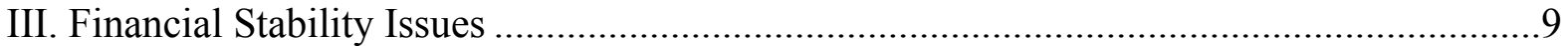

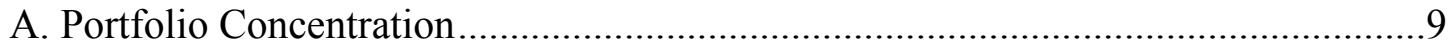

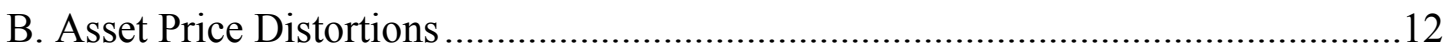

C. Pension Fund Investment in Foreign Assets ................................................... 14

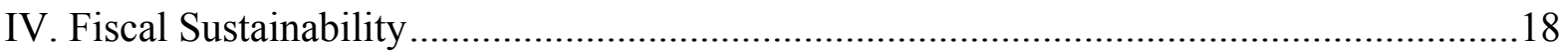

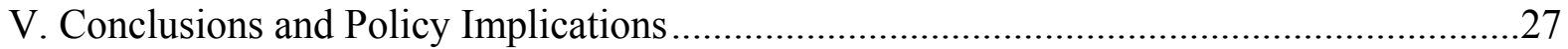

Tables

1. Total Estimated Effects of Pension Reform on GDP Growth......................... 4

2. Gross Returns of Pension Funds............................................ 8

3. Selected Latin American Countries: Pension Funds Portfolio Composition,

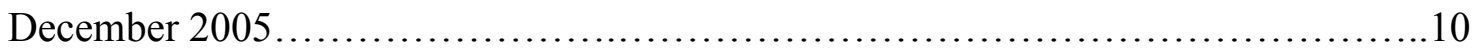

4. Pension Funds Share of Government Debt Markets.................................12

5. Peru: Yields on Dollar-denominated Sovereign and Corporate Bonds issued in

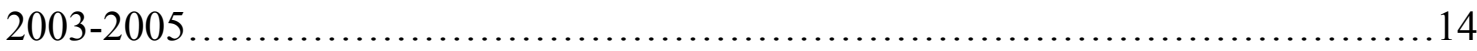

6. Foreign Investment Limits and Allocations...................................... 15

7. Selected Latin American Countries: Determinants of Fiscal Cost of Pension Reform

Figures

1. Selected Countries: Pension Fund Assets and Capital Markets.........................5

2. Unfunded Pension Liabilities of Countries with Reformed Pension Systems............. 6

3. Selected Latin American Countries: Pension Funds Portfolio Composition................ 10

4. Argentina: Share of Government Debt in Pension Funds Portfolios..................... 11

5. Chile: Pension Fund and Asset Returns............................................ 13

6. Chile: Pension Funds Portfolio Limits and Allocations.............................. 16

7. Chile: Central Government and Pension Deficit..................................... 20

8. Peru: Fiscal Costs of the Pension Reform......................................... 21

9. Bolivia: Initial Projections vs. Actual Pension Costs................................. 22

10. Selected Latin American Countries: Stress Test on Pension Deficit Projections.......... 24

11. Selected Latin American Countries: Primary Fiscal Balance and Public Debt (with and without pension reform) ...................................... 25

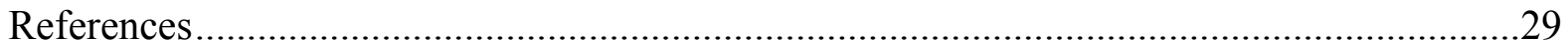




\section{INTRODUCTION}

1. Important pension reforms have been undertaken in many Latin American countries. Following Chile, several other countries in the region have adopted variants of a funded, privately managed, defined-contribution individual accounts retirement systems. ${ }^{2}$ These reforms were largely aimed at improving income security for retirees and the elderly, but also sought to address a number of other objectives, such as improving fiscal sustainability, supporting growth, and the development of local securities markets.

2. Recent assessments of these reforms suggest that they have had a mixed record relative to these goals. The experience of Chile over the past two decades and a half has been a clear success, with reforms contributing to increased savings and growth, and to the development of capital markets and financial deepening. The experience in other countries, however, seems less clear cut, partly reflecting the fact that pension reforms have occurred relatively recently and have not had the same time to bear fruit, and partly because there was less scope to introduce the same range of supporting structural reforms.

3. Against this background, this paper reviews the pension reforms in Latin America and suggests that notwithstanding the considerable gains that have been achieved, their promise in two important areas has not been fully achieved.

- Financial market development and stability. The experience in the region suggests that regulatory limits on pension funds foreign investments have undoubtedly contributed to the development of local financial markets. However, this impact has largely been felt in the government bond market, and the rapid growth of pension funds has at times distorted the prices of domestic securities. Although there seems to be a case for relaxing constraints on investing abroad, this has been resisted in many cases owing to concern regarding possible foreign exchange risk or the impact that a more liberal environment might have on the volatility of the exchange rate.

- Macroeconomic stability. Pension reforms certainly improved fiscal solvency in most countries, reflecting the beneficial effects of parametric reforms and/or phasing out of pay-as-you-go (PAYG) programs. However, the diversion of workers' contributions to private asset managers, and the payment of previous contributions to those who moved to the new systems, generated fiscal pressures that were not always accommodated in the rest of the budget. Thus, reforms in many cases resulted in

\footnotetext{
${ }^{2}$ Most countries still saw the need to continue the PAYG system for older workers during a transitional period, and the compromise was to move to what the World Bank refers to as the multi-pillar framework (Holzmann, 1999).
} 
fiscal deficits that many times exceeded the ones envisaged at the beginning of the reform process, suggesting a somewhat disappointing record in terms of macroeconomic stability.

4. The paper is organized as follows. The next section provides a brief and selective overview of pension reforms in Latin America, and is followed by a section on financial stability issues and another on fiscal sustainability issues. A final section concludes with some policy recommendations.

\section{OVERVIEW OF THE IMPACT OF REFORMS}

5. Most Latin American countries adopted pension reforms in the 1980-90s, that were variants of what the World Bank has called a "multi-pillar" approach to the reform of pension systems and programs. ${ }^{3}$ These reforms were intended to achieve a range of benefits, including an improvement in old age retirement security, an increase in national saving, the development of domestic capital markets, and fiscal sustainability (for a recent review see World Bank, 2006). This section provides a brief and selective overview of some of these issues.

6. Most pension reforms in the region are too recent to assess their macroeconomic impact, but the Chilean experience has provided important empirical evidence on this point. Corbo and Schmidt-Hebbel (2003) conclude that pension reform increased Chile's average annual GDP growth rate by 0.5 percent in 1980-2001. This reflected in roughly equal parts the boost that reform gave to saving and investment rates, the stimulus it provided to labor participation rates, and

Table 1. Total Estimated Effects of Pension Reform on GDP Growth (In percent)

\begin{tabular}{|c|c|}
\hline Real average growth of the GDP in 1980-2001 & 4.63 \\
\hline \multicolumn{2}{|c|}{ 1. Estimated effects of the reform on GDP growth } \\
\hline $\begin{array}{l}\text { 1. Saving and investment } \\
\text { 2. Labor markets }\end{array}$ & 0.13 \\
\hline 2.1 Increase in employment & 0.07 \\
\hline 2.2 Increase in productivity & 0.03 \\
\hline 3. Financial development and TFP & 0.2 \\
\hline Total* $^{*}$ & 0.49 \\
\hline
\end{tabular}

* The total is calculated as a compound rate and is therefore not equivalent to the sum of the individual effetcs.

Source: Corbo and Schmidt-Hebbel, Macroeconomic Effects of Pension Reform in Chile.

the impact that financial sector development had on total factor productivity (Table 1).

7. Indeed, pension reforms have had a significant effect on financial market development in most countries. The growth in pension funds assets under management

\footnotetext{
${ }^{3}$ In broad terms, the first pillar constitutes the mandatory, safety net part of the pension system, usually organized as PAYG. The second pillar is a mandatory, individual savings program, while the third is a voluntary, complementary savings program.
} 
(AUM) has been a major driving force of the development of medium and long-term domestic government bond markets and, to a lesser extent, corporate bond and equity markets. Figure 1 shows for a selected sample of countries that AUM has helped drive rapid increases in bond and equity market capitalization, especially in the larger countries. ${ }^{4}$ The development of corporate bond and equity markets has been limited by the issuers' size, regulatory limits on pension fund holdings of lower-rated bonds, as well as weak corporate governance and disclosure (see Roldos, 2003, and IMF, 2005).

Figure 1. Selected Countries: Pension Fund Assets and Capital Markets (in percent of GDP)

1. Chile

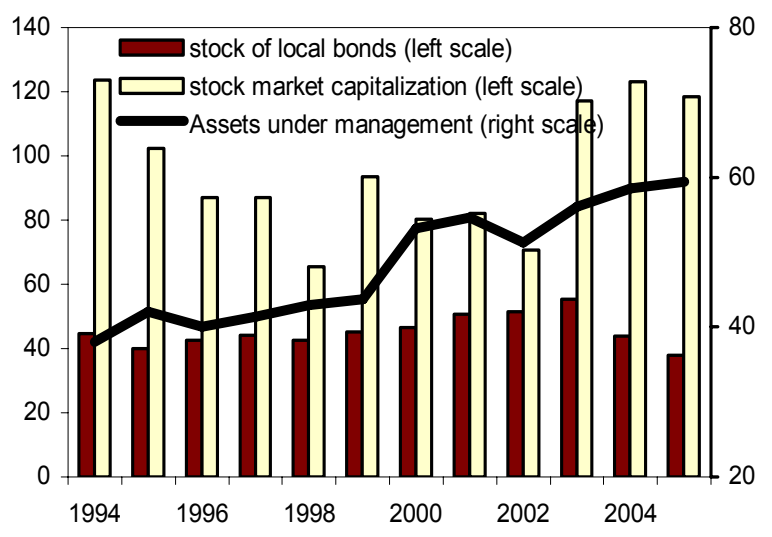

\section{Colombia}

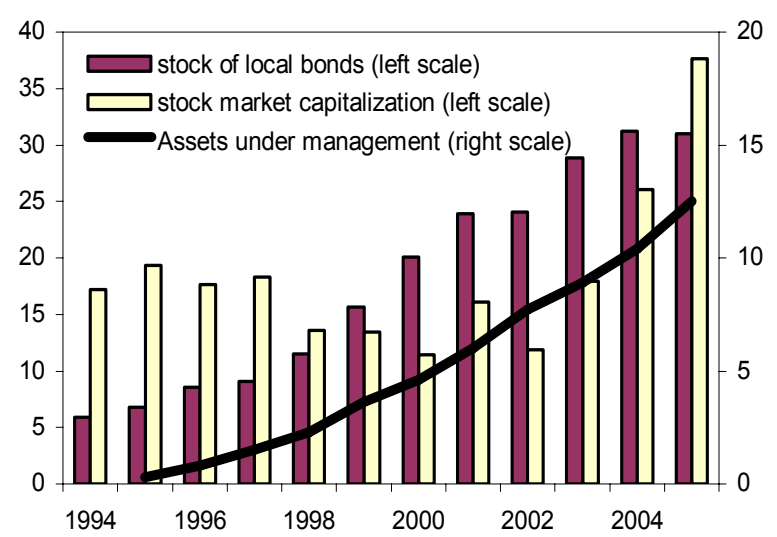

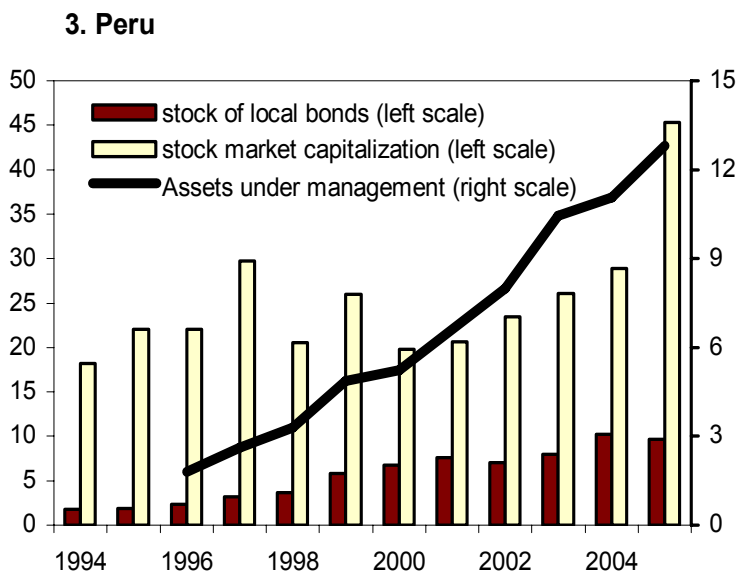

Source: BIS, IFC, AIOS and Staff Estimates
4. Mexico

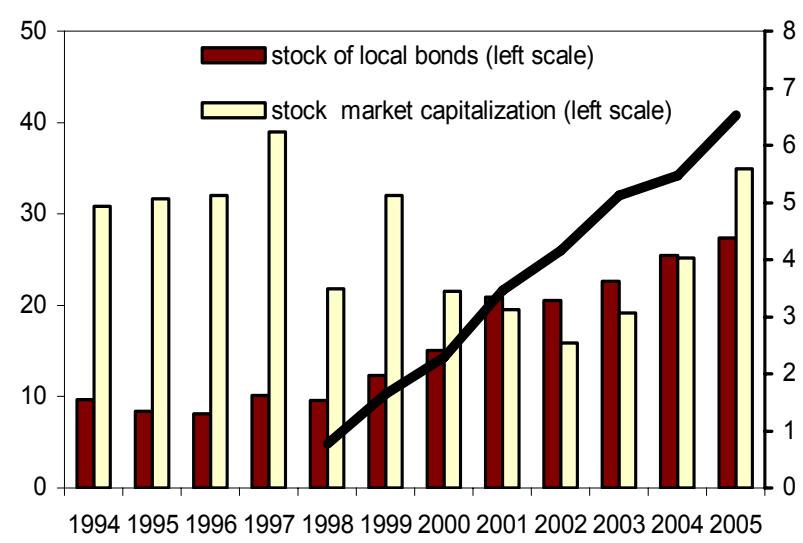

\footnotetext{
${ }^{4}$ Catalan, Impavido and Musalem (2000) show that in some cases this association reflects causality from pension funds to the growth of securities markets.
} 
8. Pension funds (PFs) have also contributed to the introduction of new financial products and the development and strengthening of institutions supporting capital markets. Walker and LeFort (2000) show that in the cases of Chile, Argentina, and Peru, pension reform contributed significantly to the accumulation of "institutional capital" (a combination of a better legal and regulatory framework, increased professionalism in the investment decision making process, and increased transparency and integrity), and to financial innovation (including annuities, mortgage bonds and other asset-backed securities, the creation of closed-end mutual funds and local rating companies, as well as improvements in securities trading and custody). ${ }^{5}$

9. Most pension reforms have improved fiscal solvency, as the unfunded liabilities of the old PAYG systems were addressed by parametric reforms and/or transfers from the budget. ${ }^{6}$ Zviniene and Packard (2002) estimate that the unfunded liabilities of the pre-reform pension systems (sometimes referred to as the implicit pension debt, IPD) sometimes exceeded the level of GDP, and they were reduced substantially in the eight cases studied -

Figure 2. Unfunded Pension Liabilities of Countries with Reformed Pension Systems

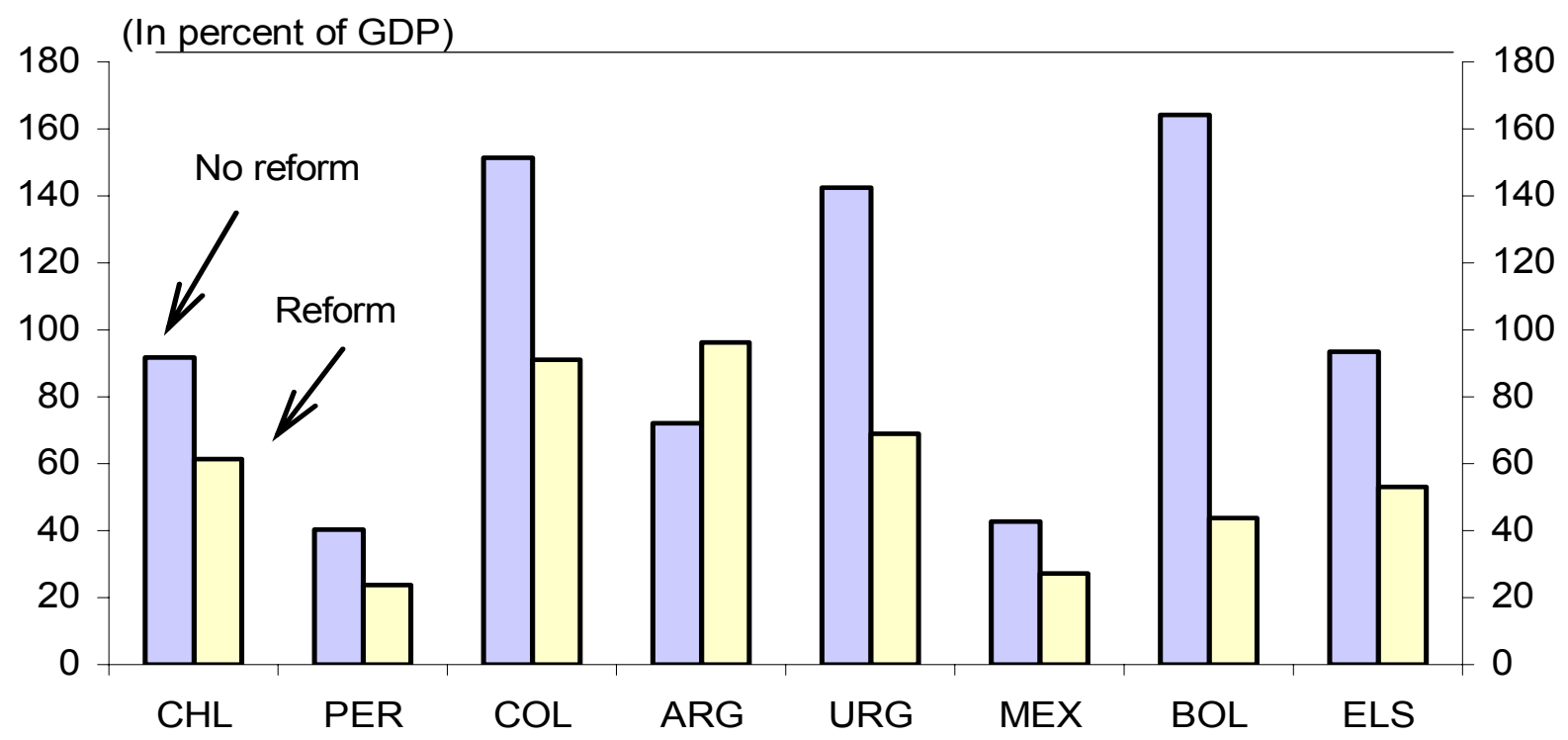

Source : Zviniene and Packard (2002); Cuevas et al (2006).

\footnotetext{
${ }^{5}$ See also Yermo, 2003.

${ }^{6}$ The main strategies to reduce the amount of debt made explicit, and implications for the path of government cash flow deficits, are discussed in Holzmann (1998).
} 
with the exception of Argentina (see Figure 2). ${ }^{7}$ This was achieved by phasing out the old PAYG programs in Chile, Bolivia, El Salvador, and Mexico, as well as by broader efforts to introduce parametric reforms, including increases in retirement ages, contribution rates and periods, as well as reductions in benefits and rationalization of multiple programs in several other countries.

10. Notwithstanding the improvements in the financial positions of the region's pension systems, a number of recent studies have pointed out areas where reforms have not delivered the expected results. ${ }^{8}$ For example, the improvement in coverage ratios has stalled and these remain very far from OECD levels (GPY, 2005). By tightening links between contributions and benefits (thus cutting the tax component of payroll deductions), reforms were expected to increase labor force participation and encourage greater "formalization" of the workforce. Although Corbo and Schmidt-Hebbel (2003) found that the share of the workforce covered increased with the reforms, GPY (2005) report cross-sectional studies where results have been less encouraging. In particular, these studies suggest that the introduction of individual retirement accounts has only a small, positive incentive effect, which takes effect only gradually as employers and workers overcome uncertainties about the new system. Moreover, coverage ratios are higher (over 50 percent of the economically active population) in relatively high income countries like Argentina, Chile, and Uruguay, and lower (less than 30 percent) in poorer countries like Bolivia, El Salvador, and Peru.

11. Another area of concern is the administrative costs of the new system. In particular, account and management fees are relatively high in most countries and absorb a large share of contributions and lower pension funds' net returns. ${ }^{9}$ Some analysts attribute the high fees to a lack of competition within the financial industries in most countries. Indeed, there appear to be strong incentives for consolidation in order to reap economies of scale in the management of accounts and collections, and to pooling risks in the provision of insurance. This suggests that there may be scope for countries to centralize collections and to take the

\footnotetext{
${ }^{7}$ Although the initial reforms in Argentina were also aimed at improving fiscal solvency, subsequent reductions in employers contributions to the PAYG programs, and the federal government assumption of the liabilities of generous pension plans for civil servants at the provincial level pension, increased the implicit pension debt.

${ }^{8}$ These include Gill, Packard, and Yermo (GPY, 2005), Holzmann and Hinz (2005), Crabbe (2005), and World Bank (2006).

${ }^{9}$ Fees are high when considered relative to current contributions, but are much lower as AUM grow and they are spread over more years. In Colombia, for instance, fees are 13.3 percent of contributions and 2.4 percent of AUM (Rudolph and others, 2006), while in Chile they are around 1 percent of AUM (close to what U.S. mutual funds charge on average, but twice as much as what large occupational pension funds in the U.S. charge).
} 
opportunity to allocate new entrants that do not choose a specific fund to lower fee funds (as done in Mexico). ${ }^{10}$

12. Questions have also been raised about the replacement rates offered after reform, which have tended to be lower than originally envisaged. In Chile, for instance, while the pension of the average current worker would replace about 60 percent of the final salary, over longer horizons the average replacement rate has been projected to decline to just over 40 percent. ${ }^{11}$ The main reason for this decline in the replacement rate is the unusually high returns experienced during the first two decades of operation of the new system, that are unlikely to be repeated for future generations. The World Bank and the ILO estimate that a 40 percent replacement ratio would provide only a

Table 2. Gross Returns of Pension Funds

\begin{tabular}{lrrrr} 
& \multicolumn{4}{c}{ Annual returns (in percent) } \\
& $\begin{array}{c}\text { Nominal } \\
\text { historical }\end{array}$ & $\begin{array}{c}\text { Real } \\
\text { historical }\end{array}$ & $\begin{array}{c}\text { Nominal } \\
\text { last 12 }\end{array}$ & $\begin{array}{c}\text { Real } \\
\text { last 12 } \\
\text { months } \\
\text { months }\end{array}$ \\
Argentina & 14.9 & $\mathbf{9 . 4}$ & 17.5 & $\mathbf{4 . 6}$ \\
Bolivia & 13.7 & $\mathbf{9 . 8}$ & 8.6 & $\mathbf{3 . 5}$ \\
Chile 1/ & 22.9 & $\mathbf{1 0}$ & 8.6 & $\mathbf{4 . 6}$ \\
Colombia & 20.7 & $\mathbf{8 . 3}$ & 24.8 & $\mathbf{1 9}$ \\
El Salvador & 12.4 & $\mathbf{9 . 3}$ & 5.8 & $\mathbf{1 . 5}$ \\
Mexico & 16.3 & $\mathbf{7 . 7}$ & 11.5 & $\mathbf{8}$ \\
Peru 2/ & 13.2 & $\mathbf{8 . 8}$ & 20.2 & $\mathbf{1 8 . 4}$ \\
Uruguay & 23.0 & $\mathbf{1 2}$ & 9.7 & $\mathbf{4 . 6}$ \\
1/ Returns correspond to the fund "tipo C" & \\
2/ Historical returns correspond to the last 120 months \\
and to the fund "tipo 2" or "mixto", which represents \\
92\% of the total.
\end{tabular}

subsistence level of income in retirement, so that higher rates would be desirable - especially in middle-income countries. ${ }^{12}$ Moreover, although the real return on pension contributions has been above 8 percent in most countries (see Table 2), the recent decline in yields suggests the risk that replacement rates in reformed systems could be even lower. And although higher replacements rates could be obtained with higher contributions rates, World Bank experience (see Holzmann and Hinz, 2005) suggests that mandated contributions in excess of 20 (10) percent are likely to be detrimental for middle- and high-income (low income) countries.

13. These recent assessments of reforms, while confirming the advantages of multi-pillar systems, have called for additional strengthening of pension systems. In particular, low coverage rates and the associated risks of increased old-age poverty have been taken to suggest the need for provisions to assure a basic income for the elderly, including in the context of non-contributory, safety net programs. ${ }^{13}$ Also, there have been proposals for

\footnotetext{
${ }^{10}$ Other policy options to lower costs are discussed in GPY (2005), Chapter 10; see also Holzmann and Hinz (2005), chapter 6, and Rudolph and others (2006).

${ }^{11}$ See Faulkner-MacDonagh (2005).

${ }^{12}$ See Holzmann and Hinz (2005). For El Salvador, for instance, Fletcher and Schipke (2006) estimate that real rates of return of less than 5 percent would likely lead to replacement rates of 17-30 percent.

${ }^{13}$ Sometimes referred to as "zero pillar," Holzmann and Hinz (2005).
} 
improving the cost effectiveness and risk management of defined contribution programs. Finally, it is often suggested that the remaining gaps in coverage should be addressed by placing a greater emphasis on measures to promote voluntary savings, including through tax incentives. $^{14}$

14. In sum, pension reforms have delivered a number of benefits including higher savings, growth and capital market development, but they could be improved in several margins. The introduction of individual accounts constitutes an important advance, especially in a region where fiscal mismanagement of previous pension systems has led to frequent default on pension promises and an erosion of retirement income. Although privatization and funding are no panacea (Barr, 2005), with a few exceptions reforms have provided a better institutional framework for pensions than in the past.

\section{Financial Stability IsSueS}

15. This section discusses the impact of pension reforms on financial markets and cautions that regulatory and other constraints on asset allocation by pension funds could lead to distortions and financial instability. Although - as noted in the previous section - the rapid growth in AUM has helped spur the development of new instruments and markets, there are also signs that this process has led to asset price distortions and excessive concentration of risk in PFs portfolios. This suggests that policymakers may wish to consider relaxation of the regulatory limits on PF investment in foreign assets, while also being mindful of the potential for increased volatility in foreign exchange (FX) markets.

\section{A. Portfolio Concentration}

16. The portfolios of Latin American PFs remain highly concentrated in government bonds. In particular, even though the share of PF holdings of government debt and bank deposits declined for the region as a whole since 1999, they remained 46 percent and 16 percent of PF portfolios on average (see Figure 3). Nonetheless, the share of government bonds varied widely across countries, ranging from under 20 percent in Chile and Peru, to more than 80 percent in El Salvador and Mexico (see Table 3). ${ }^{15}$ Foreign investments and securities issued by non-financial institutions (mostly corporate bonds) have increased their shares of the average portfolio, with Chilean funds leading other countries by far, with 30 percent of AUM invested in foreign assets. ${ }^{16}$

\footnotetext{
${ }^{14}$ See GPY (2005).

${ }^{15}$ Exposure to the sovereign may be larger if one were to consider central bank securities; in the case of Uruguay, for instance, this would bring exposure to the sovereign to almost 85 percent of assets.

${ }^{16}$ Recent reform proposals in Chile will increase the limits on foreign investments even further, with a longterm limit of 80 percent.
} 
Figure 3. Selected Latin American Countries: Pension Funds Portfolio Composition
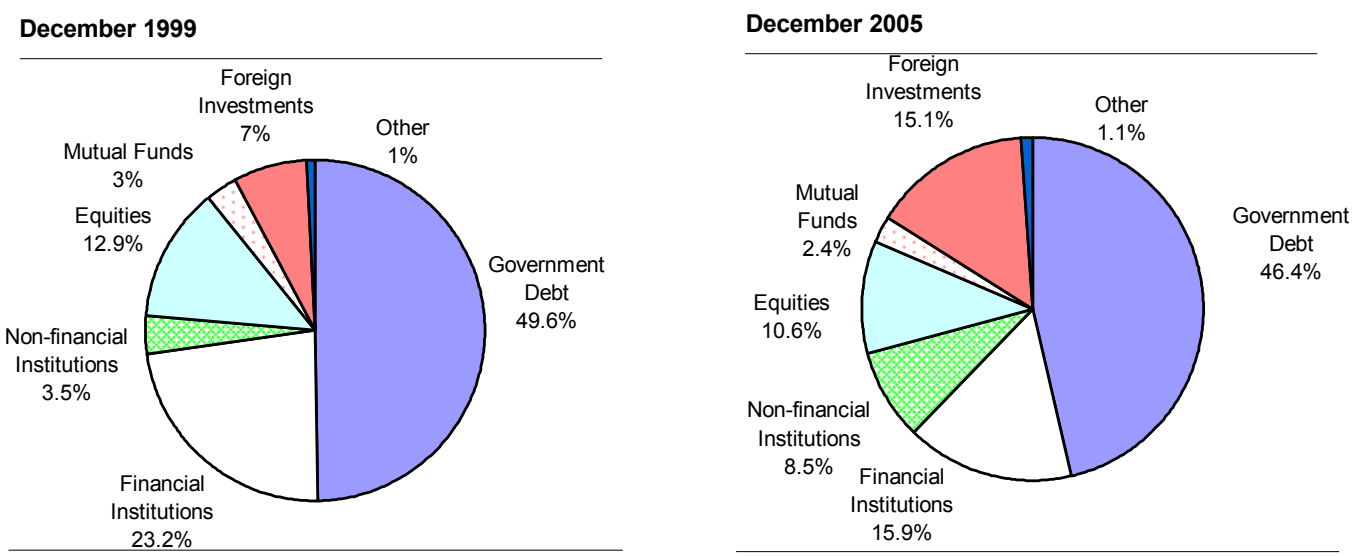

Table 3. Selected Latin American Countries: Pension Funds Portoflio Composition, December 2005

\begin{tabular}{|c|c|c|c|c|c|c|c|}
\hline & $\begin{array}{c}\text { Government } \\
\text { Debt }\end{array}$ & $\begin{array}{l}\text { Financial } \\
\text { Institutions }\end{array}$ & $\begin{array}{l}\text { Non-financial } \\
\text { Institutions }\end{array}$ & Equities & Mutual Funds & $\begin{array}{c}\text { Foreign } \\
\text { Investments }\end{array}$ & Other \\
\hline & \multicolumn{7}{|c|}{ in percent of total } \\
\hline Argentina & 60.9 & 5.1 & 1.8 & 13.4 & 8.1 & 8.9 & 1.8 \\
\hline Bolivia & 70 & 6.8 & 13.5 & 6.3 & & 2.5 & 0.9 \\
\hline Chile & 16.4 & 28.9 & 6.8 & 14.7 & 2.8 & 30.2 & 0.2 \\
\hline Colombia & 47.3 & 10.4 & 14.4 & 11.3 & 2 & 10.4 & 4.3 \\
\hline EI Salvador & 81 & 12.7 & 6.3 & 0 & & & \\
\hline Mexico & 82.1 & 4.2 & 11.8 & 0.4 & & 1.5 & \\
\hline Peru & 20.3 & 11.1 & 10.7 & 36.4 & 2.8 & 10.1 & 8.7 \\
\hline Uruguay & 59.5 & 36.8 & 2.7 & 0.1 & & & 0.9 \\
\hline Total & 46.4 & 15.9 & 8.5 & 10.6 & 2.4 & 15.1 & 1.1 \\
\hline
\end{tabular}

17. Although this suggests a possibly unhealthy concentration of risk, there are several arguments in favor of a relatively large portfolio allocation in government bonds. First, PF acquisition of government bonds has helped smooth the transition to a funded system, enabling governments to finance the residual obligations of the old PAYG systems (Campbell and Feldstein, 2001). Second, PF investment in government bonds can be viewed as helpful in developing local bond markets, by establishing a yield curve and contributing to the acceptance and use of indexed bonds (Mathieson and others, 2004). Third, given that most likely PF managers would be relatively inexperienced in risk management in the early stages of reform, it would seem appropriate to constrain PF portfolio choices initially.

18. Regulations have reflected these considerations to varying degrees in different countries. Most governments have imposed floors on holdings of government bonds. In Uruguay, for instance, funds are required to invest 40 to 60 percent of their assets in government securities, while in Bolivia the two existing pension funds must invest together a minimum of $\$ 180$ million annually in government bonds. At the same time, however, most 
countries have also placed ceilings on the pensions funds' exposure to the government, to encourage diversification. In Argentina and Colombia, for instance, funds are allowed to hold government bonds up to half their AUM.

19. The recent Argentine crisis has highlighted the risks involved in a concentrated exposure to the sovereign. As the government tried to decrease the cost of servicing its debt in 2001, pension fund companies and banks had to make asset allocation decisions that they probably would not have made otherwise (see Garcia Cantera and others, 2001). The subsequent default, devaluation, and pesoization of deposits and local bonds has caused losses to the pension funds that are difficult to quantify but are nevertheless likely to be significant. Figure 4 shows that the pension funds large holdings of government debt, that were close to the 50 percent ceiling before the first debt exchange in 2001, were restructured and

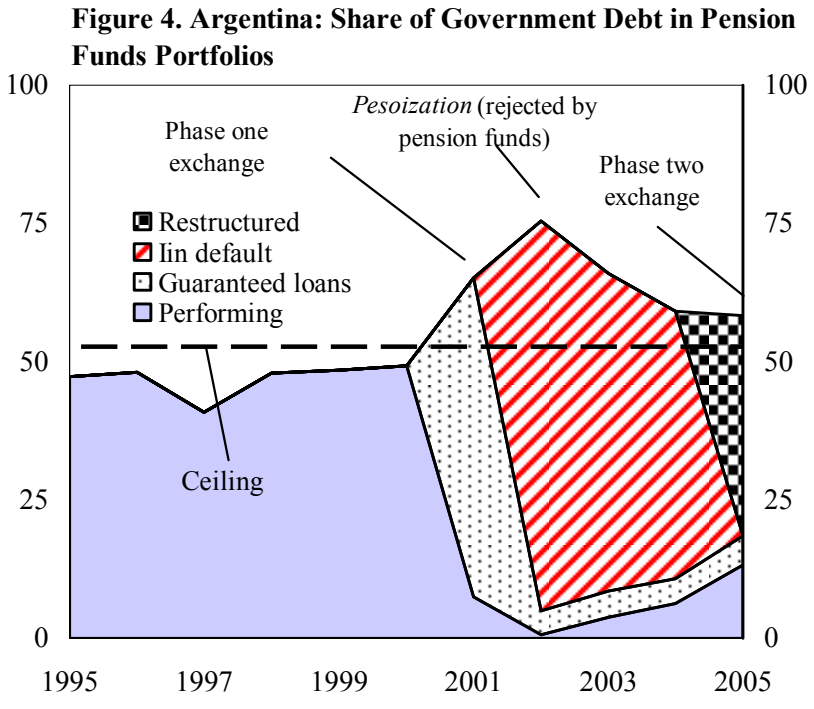
remain on the pension funds' bookssome of it booked at "technical" values that do not fully reflect the haircuts of the second exchange. ${ }^{17}$

20. Notwithstanding the experience in Argentina, pension reforms in the region appear to have been relatively unaffected in the face of crises. For example, Uruguay's debt exchange had only a modest impact on PF portfolios, and the "forced" change in the currency denomination of Bolivia's government bonds probably improved the composition of PF portfolios. In both cases, the motivation was to reduce the dollarization of government liabilities and avoid a larger default as the currency depreciated sharply. The changes led to an increase in the share of indexed bonds to 29 percent of total AUM in Bolivia and to 44 percent in Uruguay by end-2005. And while the changes were not introduced on a voluntary basis, they seem to have had a limited adverse effect on the credibility of the pension reforms.

\footnotetext{
${ }^{17}$ The Superintendency of Pension Funds (SAFJP, 2002) notes, however, that the pension fund administrators has managed to prevent to a large extent the fall in asset values in real terms, even when the dollar value of AUM declined substantially. As of end-2005, restructured debt accounted for around 40 percent of AUM, the bulk of which are quasi-par bonds that are not valued at market prices.
} 
21. The increasing role of pension funds in local bond markets raises important issues related to debt management and the development of local securities markets (Table 4). Pension funds are a source of "captive" demand for government debt, lowering the cost of funds for the sovereign with the possibility of several undesirable macro and microeconomic consequences. First, fiscal discipline may be lessened by the easier access to bond financing. Second, low yields would tend to adversely affect PF returns and the replacement ratios obtained by future Table 4. Pension Funds Share of Government Debt Markets (in percent)

pensioners. Third, there would tend to be lesser incentives for governments

\begin{tabular}{lccc} 
Country & 31-Dec-98 & 31-Dec-02 & 31-Dec-05 \\
\hline Argentina & 5.1 & 15.1 & 8.6 \\
Bolivia & 33 & 36.4 & 48.5 \\
Chile & 63.8 & 63.8 & 77.5 \\
Colombia & & 7.6 & 13.6 \\
El Salvador & 2.6 & 16.3 & 36.3 \\
Mexico & 14.5 & 16.8 & 24 \\
Peru & 0.4 & 2.8 & 6.4 \\
Uruguay & 6.5 & 8.9 & 14.8 \\
\hline Total & $\mathbf{1 8 . 0}$ & $\mathbf{2 1 . 0}$ & $\mathbf{2 8 . 7}$ \\
Source: AlOS & & &
\end{tabular}
to accommodate the PF demand for (say) indexed instruments to protect against inflation risk. This suggests the possible merits of ensuring that debt management policies are broadly consistent with pension fund investment limits and portfolio needs, as well as concerted efforts to encourage the development of private securities markets.

\section{B. Asset Price Distortions}

22. The rapid growth of pension fund's AUM has generally helped develop local instruments and markets, but in a number of countries the supply of new securities has been slow to respond, leading to concerns that asset prices have been distorted. This experience has highlighted the importance of coordinating pension reform and the relaxation of regulatory limits on pension fund investments with steps to build financial markets infrastructure. This section illustrates how asset price distortions have arisen in equity and bond markets, and discusses policy options to mitigate them.

23. The Chilean stock market delivered extraordinary returns following the removal of a four-year ban on pension funds' investments in equities. Between 1981 and 1985 pension funds could only hold government and corporate bonds, mortgage-backed securities, or bank deposits. In 1985, pension funds were permitted to allocate up to 30 percent of their portfolio in equities, and the increase in pension fund demand helped cause equity prices to increase at an average annual rate of over 30 percent until 1993, when the 30 percent cap was reached (see Figure 5). Although a number of other factors contributed to the price boom, including the privatization of government enterprises and GDP growth rates that reached around 7 percent, most analysts agree that pension funds demand was a major driver. 
Figure 5. Chile: Pension Fund and Asset Returns (in percent)

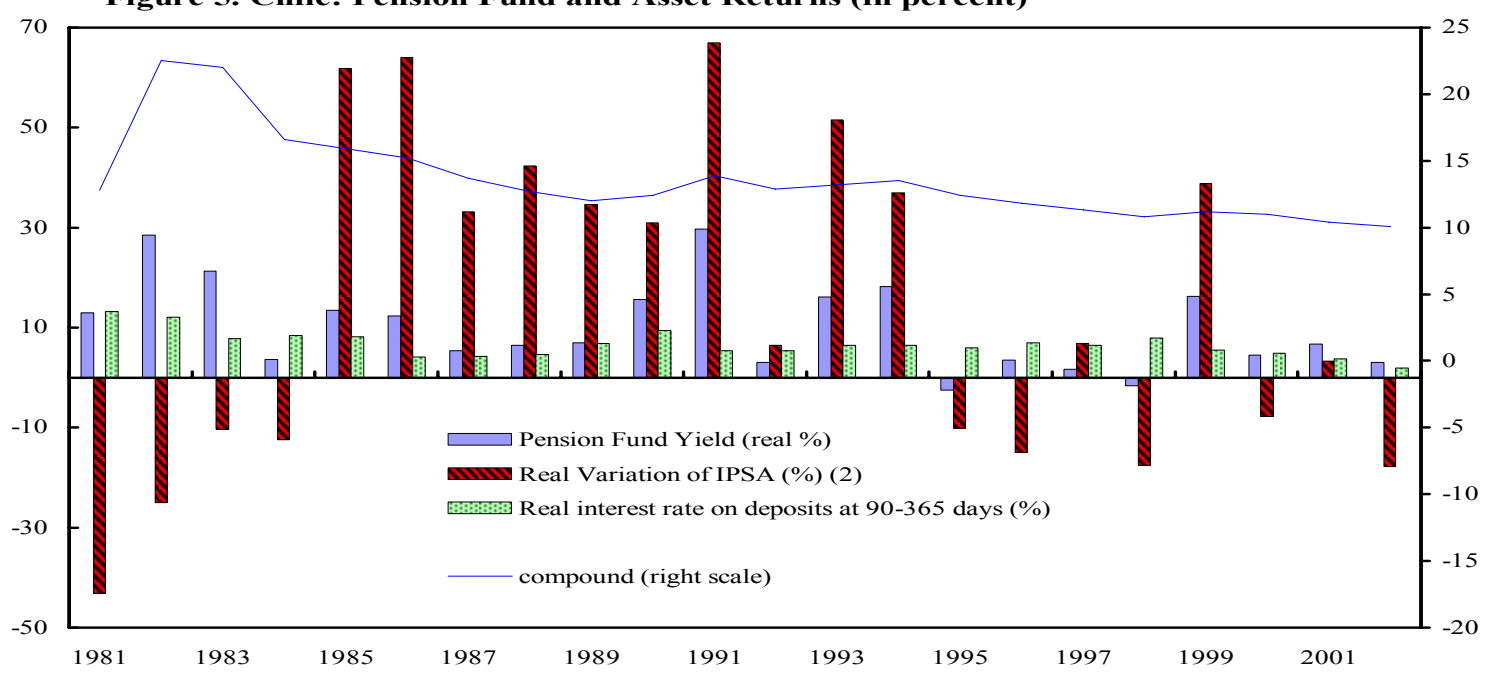

Source: PrimaAmerica Consultores

24. Regulatory limits on PF investments have also led to distortions in bond prices in a number of countries. In Mexico, for instance, the yield curve on external debt (swapped to pesos) was much higher than the local bond yield curve in early 2003, reflecting in part limits on pension funds ability to arbitrage the yield differentials (see Figure). ${ }^{18}$ In Peru, caps on investments abroad and the lack of investment alternatives for the PF's increasing AUM meant that local corporate borrowers were able to issue dollar-denominated bonds in the local market at yields lower than the sovereign - despite their lower credit quality and ratings (see Table 5). Similarly, in Colombia, the ceiling on holdings of government bonds has created an artificially strong demand for corporate bonds that
Mexico: External and Domestic Yield Curves (in percent)
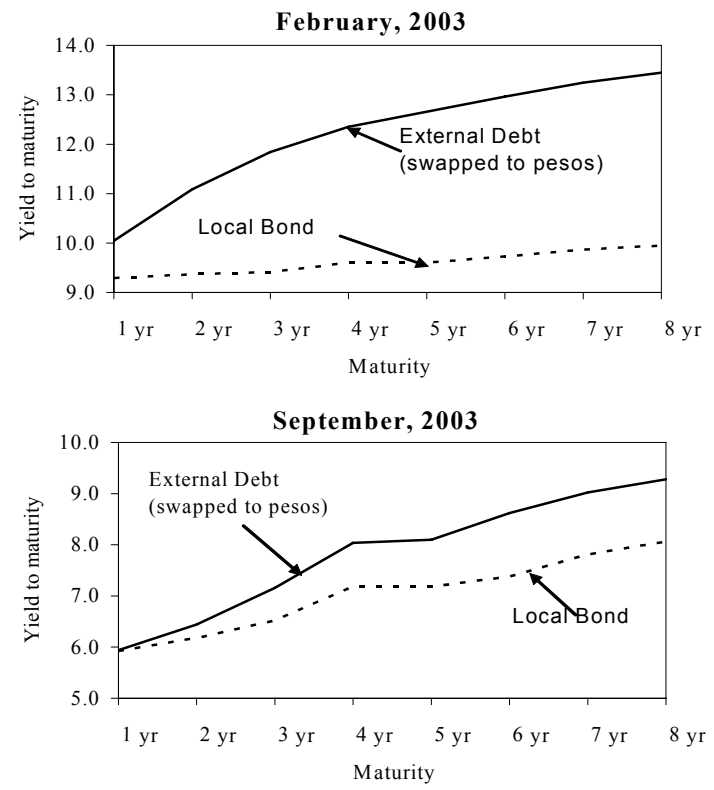

Source: JP Morgan

\footnotetext{
${ }^{18}$ The fact that pension funds could not hold more than 10 percent of their assets in Mexican external debt, combined with their inability to engage in cross-currency swaps and restrictions on short-selling the local bonds, prevented the convergence of both curves. The fact that other market participants exploited these differentials contributed to a gradual convergence of the curves later in the year, as shown in the lower panel of the figure (see IMF, 2004, for further details).
} 
resulted in very low spreads above the sovereign (see Rudolph and others, 2006).

Table 5. Peru: Yields on Dollar-denominated Sovereign and Corporate Bonds issued in 2003-2005

TRANSMANTARO

$\begin{array}{ccccccc}\text { Coupon* }^{*} & \text { Sovereign YTM } & \text { Spread }^{* *} & \text { Issue Date } & \text { Maturity Date } & \text { Coupon Type } & \text { Currency } \\ 6.00 & 7.29 & -129 & 12 / 11 / 2003 & 12 / 11 / 2011 & \text { FIXED } & \text { USD } \\ 6.25 & 7.29 & -104 & 12 / 11 / 2003 & 12 / 11 / 2012 & \text { FIXED } & \text { USD }\end{array}$

ELECTROANDES S.A.

$\begin{array}{ccccccc}\text { Coupon* }^{*} & \text { Sovereign YTM } & \text { Spread }^{* *} & \text { Issue Date } & \text { Maturity Date } & \text { Coupon Type } & \text { Currency } \\ 6.44 & 7.43 & -99 & 6 / 9 / 2003 & 6 / 9 / 2013 & \text { FIXED } & \text { USD } \\ 6.00 & 7.73 & -173 & 9 / 30 / 2003 & 9 / 30 / 2015 & \text { FIXED } & \text { USD } \\ 5.88 & 7.29 & -142 & 12 / 11 / 2003 & 11 / 12 / 2013 & \text { FIXED } & \text { USD }\end{array}$

DUKE ENERGY EGENOR

\begin{tabular}{ccccccc} 
Coupon* $^{*}$ & Sovereign YTM & Spread $^{* *}$ & Issue Date & Maturity Date & Coupon Type & Currency \\
3.75 & 4.28 & -53 & $11 / 7 / 2003$ & $11 / 7 / 2008$ & FIXED & USD \\
5.31 & 5.04 & 28 & $8 / 9 / 2005$ & $8 / 9 / 2009$ & FIXED & USD \\
6.50 & 5.04 & 147 & $8 / 9 / 2005$ & $8 / 9 / 2010$ & FIXED & USD \\
\hline
\end{tabular}

Footnotes:

$\left(^{*}\right)$ in percent; most corporate bonds are not priced and therefore are considered 'par' bonds, in which case coupon rate=yield-to-maturity

$\left({ }^{* *}\right)$ in basis points, spread is computed as a difference between corporate YTM and YTM of a sovereign bond of similar maturity at the time of the corporate bond issuance

Source: Bolsa de Valores de Lima

25. Experience in the region suggests that these distortions can be ameliorated by the early adoption of capital market reforms and an easing of constraints on PF investments abroad. For example, while introducing a broad range of reforms, Chile privatized a number of public enterprises and established an environment conducive to the development of capital markets. This was reinforced by the approval of two other comprehensive capital market laws aimed at improving the pension system and increasing the number of instruments available for investment. In Peru, regulatory steps were taken to facilitate the introduction of infrastructure-related securities and structured instruments (Masias, 2005). In Colombia, a 2005 law on corporate governance is expected to support the issuance of more equity, and PFs are already taking advantage of a supportive legal and regulatory environment to invest in private equity (Rudolph and others, 2006). Of course, the scope for smaller countries to develop meaningful local securities markets is more modest, suggesting that the emphasis instead could be on easing constraints on PF investments abroad. The implications of this route are discussed in further detail below.

\section{Pension Fund Investment in Foreign Assets}

26. Most countries restrict pension funds' investments in foreign assets, especially during the early stages of reform, for a number of reasons. First, countries want to develop local capital markets and use PF investments to help spur domestic investment. Second, pension 
funds are subject to strict disclosure requirements, and investments abroad are harder to monitor. ${ }^{19}$ Third, regulators worry that overseas investments may be expensive, including as a result of a duplication in asset management fees when the foreign instruments are mutual funds. And finally, there is a concern that pension funds may exacerbate volatility in foreign currency markets in their home country, especially as they grow and exhibit herding behavior.

27. As a result of these concerns, the regulatory ceilings on investments in foreign assets are relatively low in Latin American countries. Pension funds are allowed to invest abroad up to 30 percent of AUM in Chile, up to 20 percent in Argentina, Colombia and Mexico, 12 percent in Peru, and zero in El Salvador and Uruguay (Table 6). Moreover, with the exception of Chile and Peru, actual allocations are much lower than regulatory limits, and generally below 10 percent of AUM. This contrasts with some small OECD countries, such as Ireland and Netherlands (where foreign assets are two-thirds of the portfolio), and to a lesser extent with the actual allocations of some medium-sized countries such as Denmark and Spain (Table 6).

Table 6. Foreign Investment Limits and Allocations

(as of December 2005)

\begin{tabular}{|c|c|c|c|}
\hline \multirow[b]{2}{*}{ Countries } & \multicolumn{2}{|c|}{ Foreign Investments $1 /$} & \multirow{2}{*}{$\begin{array}{c}\begin{array}{c}\text { Foreign Currency } \\
\text { Investments }\end{array} \\
\text { Actual }\end{array}$} \\
\hline & Limit & Actual & \\
\hline Argentina & 20 & 8.9 & 20.8 \\
\hline Bolivia & $50 / 102 /$ & 2.5 & 66.8 \\
\hline Chile & 30 & 30.2 & 30.6 \\
\hline Colombia & 20 & 10.4 & 14.4 \\
\hline El Salvador & 0 & & 0 \\
\hline Mexico & 20 & 1.5 & 1.1 \\
\hline Peru & 12 & 10.1 & 46.7 \\
\hline Uruguay & 0 & & 45.2 \\
\hline \multicolumn{4}{|l|}{ Memo: } \\
\hline Canada (2001) & & 21.4 & \\
\hline Denmark (2001) & & 25 & \\
\hline Ireland (2001) & & 67.8 & \\
\hline Netherlands (2001) & & 65 & \\
\hline Spain (2001) & & 34.3 & \\
\hline \multicolumn{4}{|l|}{$\begin{array}{l}\text { Sources: AIOS, IMF. } \\
\text { 1/ By residence of issuer }\end{array}$} \\
\hline $\begin{array}{l}\text { 2/ The law states that the } c \\
\text { has not been issued yet }\end{array}$ & ank will set a c & Detween 10 a & ercent of AUM; regulation \\
\hline
\end{tabular}

\footnotetext{
${ }^{19}$ The most natural instruments are global mutual funds, and it is sometimes difficult to obtain a detailed composition of the assets of a mutual fund at the frequency required by the regulators.
} 
28. The Chilean experience suggests that other countries in the region are likely to see a large increase in foreign investments in the near term. The limits on overseas investments by Chile's pension funds were raised very gradually from zero in the early 1990s to 30 percent in June 2002 (Figure 6). However, Chile's pension funds were slow to take up the increased regulatory room, partly owing to high domestic assets returns. After two years of large negative returns in the local stock market, a rapid reallocation toward foreign assets began in 1997, and the funds are currently at the regulatory limit.

Figure 6. Chile: Pension Funds Portfolio Limits and Allocations

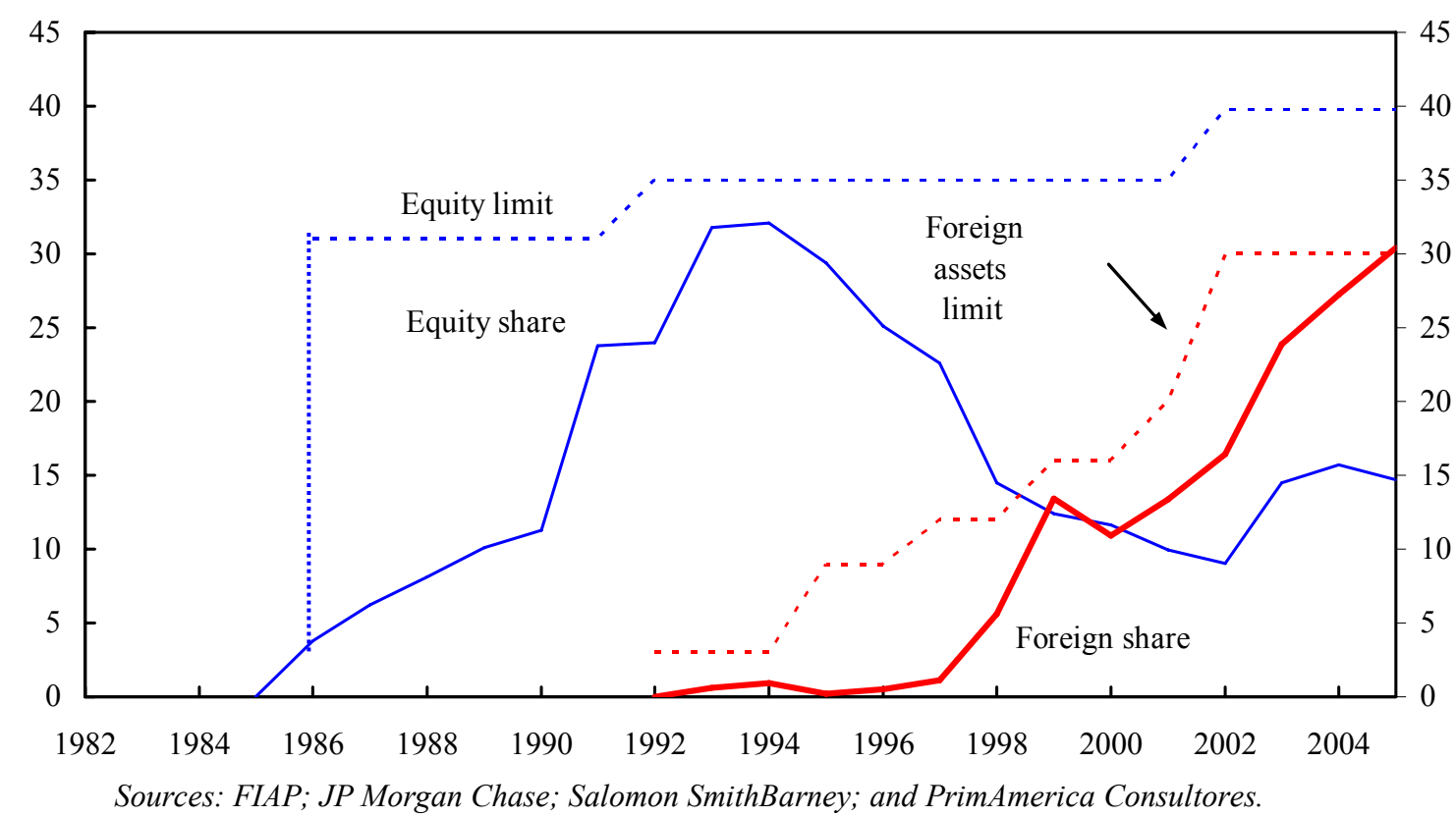

29. The holdings of foreign assets by PFs in Latin America also appear to be low relative to estimates of optimal portfolios. Although there is considerable debate about how to define optimality for PFs, a recent study calculates a static mean-variance optimal portfolio for Chile and suggests that the optimal holding of foreign assets would be around 48 percent of AUM (Walker, 2005). A similar study for Colombia (Jara and others, 2005) finds that the optimal allocation would be between 44 and 70 percent of AUM. ${ }^{20}$

\footnotetext{
${ }^{20}$ These types of calculations do not take into account factors such as human capital, housing assets, and the risks of low interest rates at retirement, which can significantly affect estimates of the optimal portfolio. Baxter and King (2001), for instance, show that since human capital is correlated with returns in local assets, the optimal portfolio with human capital should incorporate a higher share of foreign assets.
} 
30. While there is general agreement that an increased share of investments in foreign assets would provide useful diversification gains, there is less agreement on the benefits of hedging the foreign currency exposure of such investments. ${ }^{21}$ Indeed, the above-mentioned studies for Chile and Colombia suggest that hedging of foreign exchange (FX) risk is not optimal - and actually, for Chile, it is optimal to borrow local currency and increase the FX currency exposure beyond what is implied by foreign investments. ${ }^{22}$ This is due to the fact that foreign currency is a natural hedge against global equity fluctuations: global equity selloffs are usually counterbalanced by local currency depreciations. ${ }^{23}$

31. One factor that can dissuade policymakers from relaxing limits on PF investments abroad is concern about the possible impact on the exchange rate. Indeed, the Chilean and Canadian experiences have shown that a sudden shift of pension funds assets abroad can contribute to exchange rate depreciation. ${ }^{24}$ In Chile, the increase in the share of foreign assets, from 2 percent by end 1997 to 12 percent by end-1999, was associated with a roughly 20 percent depreciation of the peso. In Canada, an increase of the foreign investment limit from 20 percent in January 2000 to 30 percent in January 2001, led to a tripling of capital outflows and contributed to a 10 percent depreciation of the Canadian dollar in the period January 2000 through January 2002. ${ }^{25}$ In both cases, however, the depreciations were also associated with a deterioration in non-energy commodity prices. More recently, further relaxation of investment limits in Canada has led foreign banks to issue bonds denominated in Canadian dollars (dubbed "Maple bonds") to tap the large PF demand. And the issuers' practice of swapping the proceeds to U.S. dollars has deepened the FX swap market and facilitated the sovereign debt management activities.

32. At times, Latin American policymakers have used changes in the limits on pension fund exposures as an FX intervention instrument. For instance, Colombia imposed a maximum FX exposure of 20 percent of pension funds' assets to stem peso depreciation pressures in 2001. Similarly, in Chile, the increase in foreign investment allocations to 20-30 percent during the past three years was aimed in part at countering the appreciation trend of

\footnotetext{
${ }^{21}$ Solnik (1998) estimates that the optimal portfolio would be the world market portfolio partly hedged against currency risk, but recognizes that there is no simple practical solution and no theoretically unquestionable benchmark for currency hedge ratios.

${ }^{22}$ In dollarized economies such as Argentina, Bolivia, Peru and Uruguay, foreign currency exposure largely exceeds foreign investments (see Table 6).

${ }^{23}$ This co-movement across equity market returns and exchange rates has been documented for a large number of countries and time periods (see Fooladi and Rumsey, 2006).

${ }^{24}$ See Patterson and Normand (2002) and Roldos (2003).

${ }^{25}$ In both cases, however, the depreciations were also associated with a deterioration in non-energy commodity prices.
} 
the peso. In Uruguay, PFs face a constraint on the total volume of trading of foreign currency they can do during a trading day. And in Bolivia, the central bank's reluctance to set the regulatory limit on foreign investments, is also attributed in part to a concern about potential pressures in FX markets.

33. A number of observers have supported the use of PF regulations to achieve exchange rate objectives. For instance, Hausmann, Rodriguez-Clare and Rodrick (2005) argue in favor of using foreign investment restrictions to fight real exchange rate appreciation, achieve a long-term growth goal, and contribute to the short term stability of the real exchange rate. Zahler (2004) has argued that exchange rate considerations could militate in favor of regulating the speed at which PFs are allowed to change their holdings of foreign assets. ${ }^{26}$ However the author also recognizes that tighter regulations of this kind could prevent rapid reallocation responses in the event thre is a need to protect the returns of the PFs.

34. However, there are several considerations that argue against using PF regulations to counter exchange rate volatility. First, even in response to large changes in the optimal holding of FX assets, pension funds are likely to change their allocations in a gradual manner (Borrero, 2005). Second, PFs are aware of their impact on FX markets and under certain markets structures their behavior may mitigate, rather than magnify, FX market volatility (Vergara and Betancourt, 2006). Indeed, pension funds have played a stabilizing role during periods of market turbulence, including by purchasing assets liquidated by other distressed financial institutions (see IMF, 2004). Finally, herding behavior by PFs is in part linked to industry-related minimum return regulations, that could be relaxed to minimize FX volatility (see Srinivas, Whitehouse, and Yermo, 2000, and Roldos 2003).

\section{Fiscal Sustainability}

35. Most pension reforms improved fiscal solvency, but many of them underestimated the fiscal effects of making explicit previously implicit pension debt. In particular, pre-reform estimates often did not fully take into account the impact of loss of contributions to individual accounts and the payment of recognition bonds to those who moved to the new partially or fully funded systems. This added in some cases more than 10 percentage points of GDP to public debt ratios and, given the different contractual nature of explicit versus implicit debt, increased the cost of borrowing for some reformers.

36. There are a number of determinants of the fiscal costs of the transition to a funded system, and they vary across countries. These include demographics; the features of the old

\footnotetext{
${ }^{26}$ This could be achieved by allowing only a fraction of their holdings to be traded per month, or by auctioning off a given amount for all PFs each month. Zahler also recommends the establishment of investment and trading accounts in PFs, with incentives to keep a large share in the former ("buy and hold" accounts) to reduce trading in the foreign currency market.
} 
system; the recognition of previous commitments; and the flexibility of choices given to the current worker at the time of the reform. ${ }^{27}$

Table 7. Selected Latin American Countries: Determinants of Fiscal Cost of Pension Reform

\begin{tabular}{|c|c|c|c|c|}
\hline & High & Medium & Low & Non-applicable \\
\hline Demographics, coverage of old system & Arg., Chi, Urug. & Col., Mex., Peru & Bol., El Sal. & \\
\hline Retirement age & Col., El Sal., Urug. & Arg., Chi., Mex. & Bol., Peru & \\
\hline Years of contribution for entitlement & Bol., Chi., Mex. & Col., El Sal., Peru & Arg., Urug. & \\
\hline Benefit parameters & Bol., Chi., Peru, Mex. & Arg., Col., Urug. & El Sal. & \\
\hline Payroll tax reduction & Bol., Chi., Mex. & Col., El Sal., Peru & & Arg., Urug. \\
\hline Members transfering to new system & Bol., Chi., El Sal., Mex. & Col., Peru & Arg., Urug. & \\
\hline Recognition Bonds & Chi. & Arg., Bol., El Sal. & Col., Peru & Mex., Urug. \\
\hline Minimum Pension & Chi. & Arg., Col., Urug. & El Sal., Mex. & Bol., Peru \\
\hline Non-contributory pension & Arg., Chi., Urug. & & & All other countries \\
\hline Other guarantees & Chi., Col. & Arg., Urug. & & All other countries \\
\hline
\end{tabular}

Source: Adapted from Mesa-Lago (2000)

37. For example, Argentina, Chile and Uruguay - countries with relatively old populations and mature PAYG pension programs - were expected to have high transitional costs. As a result, Argentina and Uruguay adopted more modest reforms than Chile, opting to allow the public PAYG to co-exist with the new funded system for part of the population. In contrast, Chile, El Salvador, Bolivia, and Mexico, phased out the old system entirely. As for the recognition of commitments under the PAYG system, Chile is at one extreme, with the issuance of recognition bonds for a large share of the contributions to the old system. By contrast, Mexico opted not to provide any recognition whatsoever, compensating by providing a life-time option to claim the benefits from the old system should they be higher than benefits under the new system at retirement. ${ }^{28}$

\footnotetext{
${ }^{27}$ Table 7 provides a more detailed description of the different costs, with a qualitative ranking of how high they were for the different countries (see Mesa-Lago, 2000).

${ }^{28}$ The lack of recognition bonds in the Uruguay case is not relevant, since the old system will pay contributors a minimum first pillar pension even if they participate in the second pillar.
} 
38. Although there are no pre-reform estimates or projections of such deficits, Chile was expected to experience large transitional fiscal costs as a result of pension reform. In the event, the operational deficit (expenditures minus revenues of the old PAYG system) was on average around 4 percent of GDP in the first 20 years of operation of the funded system, with the deficit peaking at around 20 years following the reform (Figure 7 ). ${ }^{29}$ The issuance of recognition bonds grew steadily over time, peaking at 1 1 $\frac{1}{2}$ percent of GDP roughly 25 years after the beginning of the reform. Minimum pensions are another component of the reform that grew steadily, and will add to the operational deficit in years to come. ${ }^{30}$

Figure 7. Chile: Central Government and Pension Deficit (as percent of GDP)

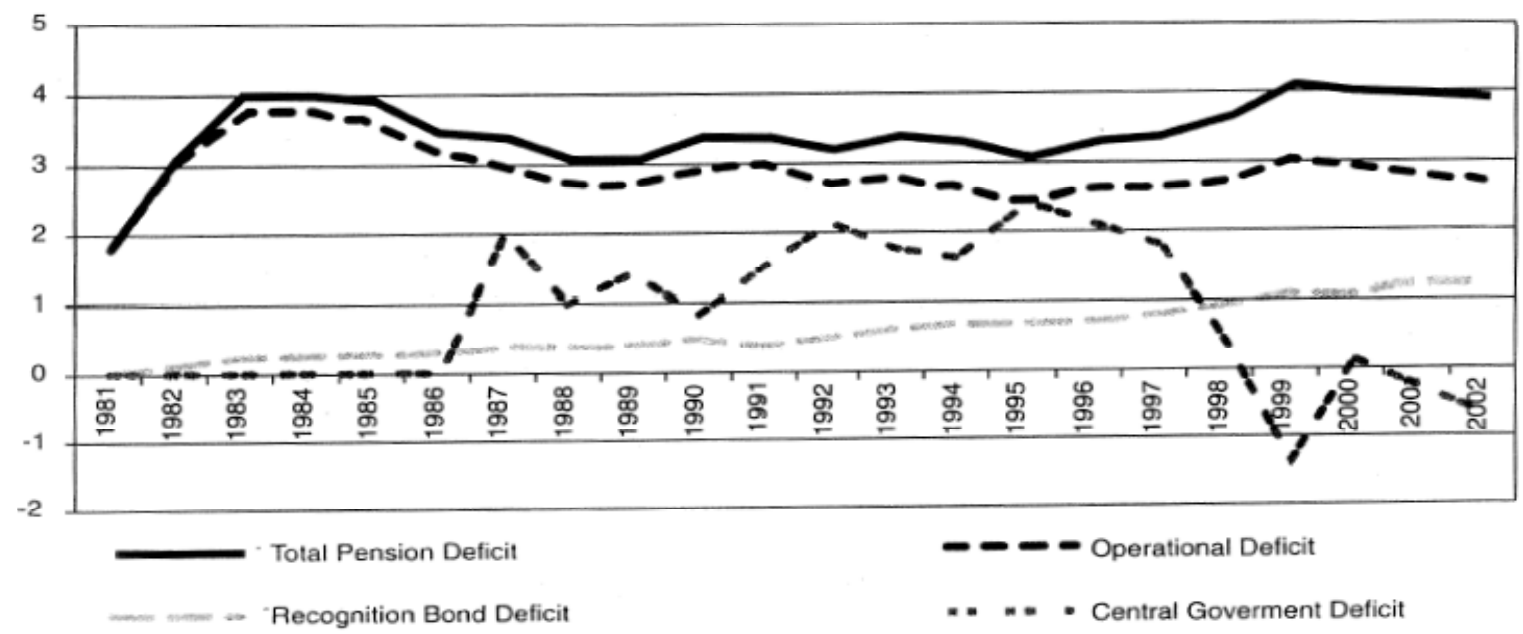

Source: Corbo and Schmidt-Hebbel (2003)

39. Other reformers, that conducted fairly thorough estimates of the fiscal costs of the transition before or during the early years of reform, found that the actual costs were generally higher than expected. A number of factors explain the deviations of actual from projected deficits, including political economy factors behind the approval and implementation of reforms, unexpected shifts to the new system (or a rush to retire under the old system), insufficient parametric reforms, and/or the impact of cyclical downturns or financial crises. Examples of the role of these factors are provided next.

40. Deviations of actual deficits from early estimates have partly reflected the complexity of the estimates, over optimism, as well as political pressures during the design of the reform.

\footnotetext{
${ }^{29}$ The other peak of 4 percent of GDP in 1983 was due in part to the sharp recession in that year.

${ }^{30}$ Minimum and non-contributory pensions increase add around 0.5 percent of GDP to the deficit numbers estimated in Corbo and Schmidt-Hebbel (see ECLAC, 2006).
} 
In Argentina, for instance, the initial reform did not include recognition bonds, but Congress decided to provide them as a precondition to pass the reform - and to add a permanent additional benefit to those who stayed in the old system, to avoid discrimination (Mesa-Lago, 2000). In Colombia, costs were boosted by a decision to allow those aged $35-40$ years to retire under the old system (without parametric reforms, see Schmidt-Hebbel, 1995). In Peru, higher initial contributions to the private system provided an incentive to stay in the PAYG; however, in 1997 the differential in contributions was reversed in favor of the private system, and the ensuing shift of members led to increased fiscal costs (Figure 8). In El Salvador, the proposed increase in the retirement age was rejected by congress during discussion of the reforms, contributing to higher fiscal costs (Samuel, 2006).

41. Unexpected shifts of groups of members that were given an option between the two systems was also a source of increased deficits in El Salvador and Uruguay, and could have the same effect in Mexico in the medium term. Both countries gave the "middle-age" group (more than 40 years old in Uruguay and 36 to 50/55 years old in El Salvador) the option to remain in a reformed PAYG or shift to the new pension system. In both cases, distrust in the old system caused higher-than-expected shifts to the private system and thus higher deficits. In Mexico, workers have the option to retire under the old system if the returns in the funded system deliver lower pensions, and analysts fear this may lead to an increase in claims on the government (Grandolini and Cerda, 1998, Mesa-Lago, 2000).

42. Large differences in the relative benefits of both systems, combined with weak implementation capacity, have also made the transition more costly than originally anticipated. For example, in Bolivia the closure of the old PAYG system was expected to lead to high initial fiscal costs, but restrictive conditions afterwards (including a lack of minimum pensions) were expected to reduce the deficit over time (Mesa-Lago, 2000). Thus, initial projections for the Bolivian reform were for the deficit to peak at 2.7 percent of GDP in 1998 and to decline steadily afterwards (see Figure 9). However, the strong incentives to retire under the old system and poor administrative controls triggered a wave of early retirement and fraudulent claims (GPY, 2005). Also, indexation of benefits to the exchange rate and the introduction of a minimum pension in 2001, brought the transitional pension deficit to almost 5 percent of GDP in 2002. 


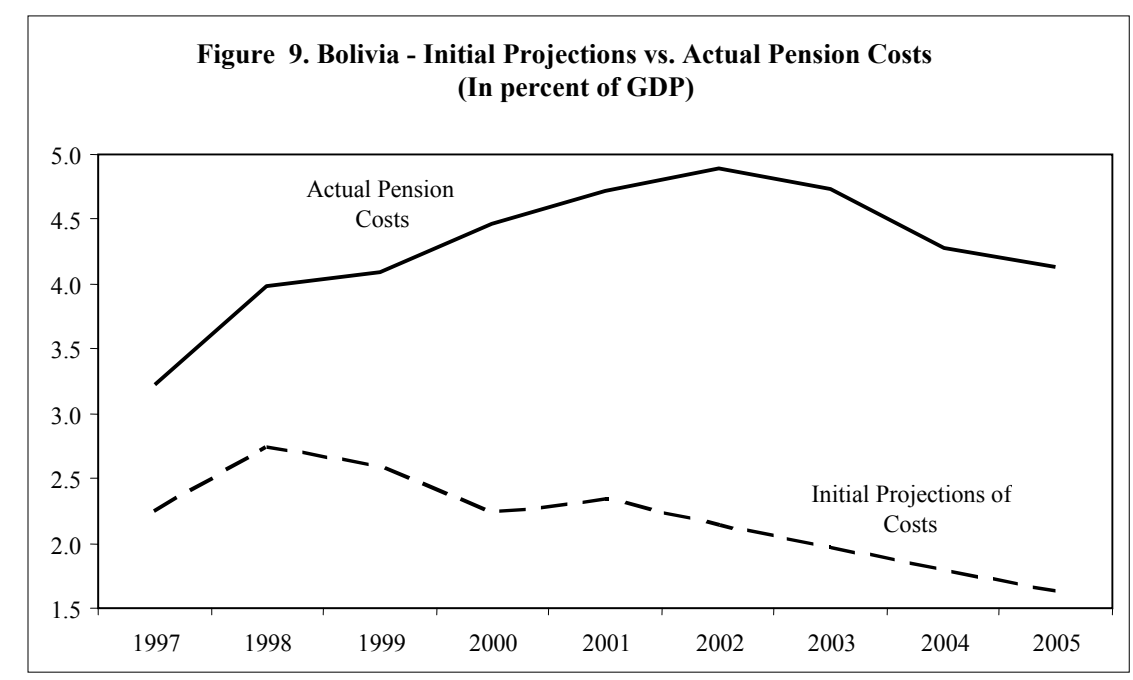

Sources: IMF Staff Estimates

43. Incomplete information on some programs, and the claims associated with recognition bonds, have also led to increased fiscal deficits. In Colombia, a number of marginal unfunded pension programs were included in a new database created in 2000 , increasing the transitional deficit by more than 3 percent of GDP (see LatinSource, 2005). A new law approved in 2003, though partially undone by the courts, and a constitutional reform in 2005, limited the impact of these unexpected claims - but the deficit is projected to remain at around 5 percent of GDP until 2010. In Chile, the projected costs of recognition bonds doubled between the 1980s and the late 1990s (Mesa-Lago, 2000). Similarly, the cost of recognition bonds in El Salvador was initially expected to peak at 1.5 percent of GDP in 2015, while more recent projections estimate this cost to peak at $2 \frac{1}{2}$ percent of GDP in $2018 .^{31}$

44. Cyclical downturns and crises have also been a major source of deviations from longrun smooth projections of transitional fiscal deficits. Chile experienced this very early on, when the economy went through a major recession during the first four years of the pension reform. Diamond and Valdes (1994) estimate that the pension deficit was about 1 percent of GDP higher in 1982-84 when measured relative to actual rather than to potential GDP. While illustrative, this estimate does not incorporate the endogenous response of pension revenues and expenditures, which are relevant for fiscal and debt dynamics. Cyclical or crises factors also magnified the pension deficits in Argentina, Bolivia and Uruguay, during 2000-03.

\footnotetext{
${ }^{31}$ The value of the original recognition bonds resulted in low pensions for early retirees of the new system, and supplementary bonds were issued in 2003 to compensate for this disadvantage of the new system. However, payments are been stretched out to minimize the increased costs (see Samuel, 2006).
} 
45. The role of cyclical factors can be properly assessed within a model that captures endogenous relationships between economic and demographic variables. One such model is The World Bank's PROST (Pension Reform Options Simulation Toolkit) model. Zviniene and Packard (2002) run PROST simulations to estimate the fiscal impact of the Latin American pension reformers using a set of common macroeconomic assumptions and idiosyncratic demographic and actuarial variables, as well as the main parameters of pension systems around 2001-02. In Figure 10, results of a sharp recession of the type experienced in Chile in 1981-84 or Argentina in 2000-2003, are reported for Argentina, Uruguay, El Salvador and Mexico. ${ }^{32}$

46. The results from "stress testing" the long-run projections with a sharp recession suggest that such a cyclical shock would add around 1 percent of GDP a year to the transitional deficit. These simulations should be taken as illustrative at best, given the fact that all these countries have modified their pension systems during the past five years. They nevertheless capture some of the dynamics of the cash flow deficit of the PAYG systems. For Argentina and Uruguay, countries that maintained a meaningful PAYG system with employee and employer contributions to finance that pillar, a recession adds approximately 1 percent of GDP a year to the transitional deficit - with the impact on employment larger in Uruguay than in Argentina. In El Salvador and Mexico, which eliminated the contributions directed to the public sector, the endogenous response of the deficit is less perceptible and the impact on GDP drives the increase in the deficit - especially in El Salvador where the effect is larger.

\footnotetext{
${ }^{32}$ The shock is assumed to produce a decline in GDP and employment of 4 percent, and a fall in real wages of 3 percent, for five years, then reversed over the following five years. I thank Yvonne Sin, Asta Zviniene and their team at the World Bank Social Protection Division for producing these simulations for this project.
} 


\section{Figure 10. Selected Latin American Countries: Stress Test on Pension Deficit Projections}

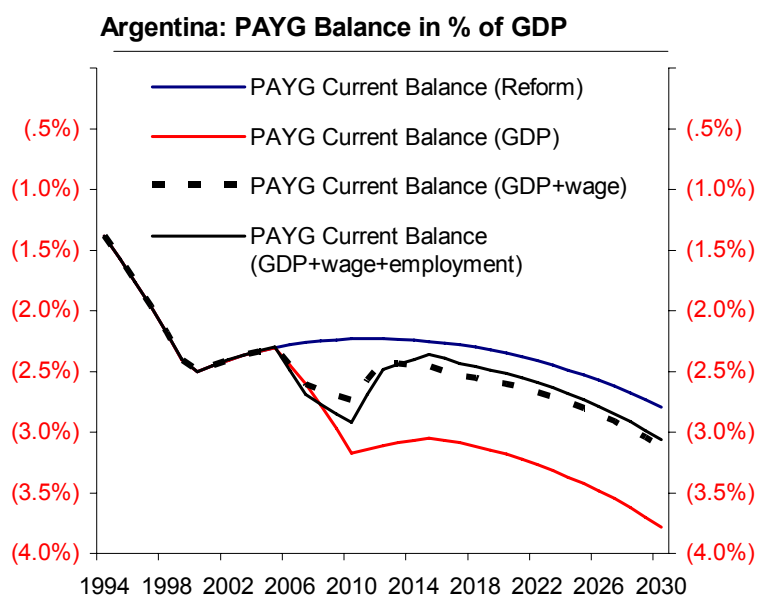

Mexico :PAYG Balance in \% of GDP

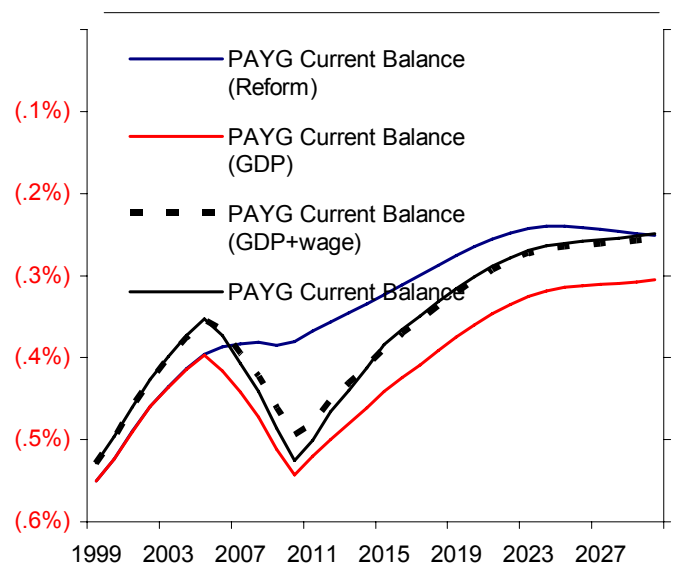

Uruguay: PAYG Balance in \% of GDP

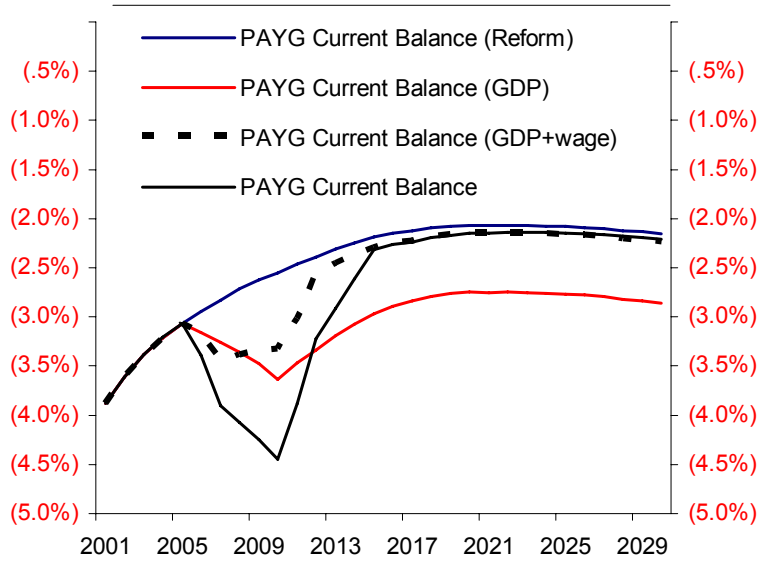

EI Salvador: PAYG Balance in \% of GDP

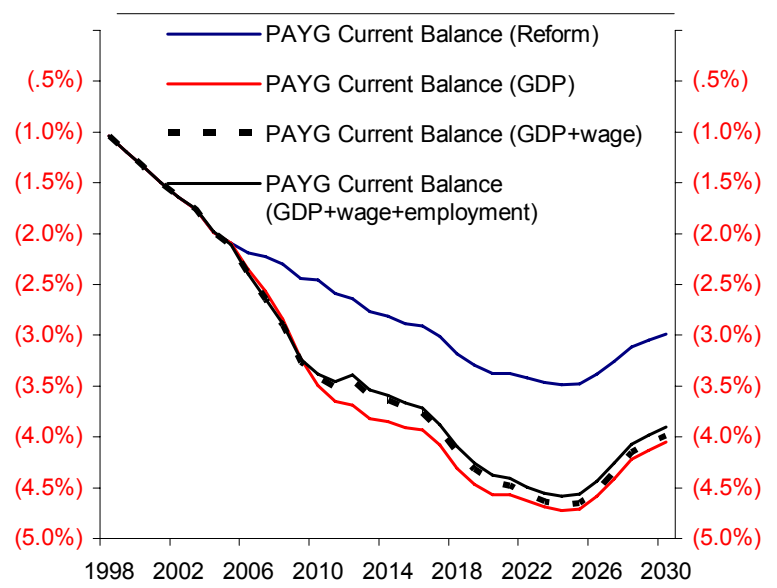

Source: World Bank Staff Estimates

47. Higher-than-expected transitional deficits, for cyclical or other reasons, have meant higher levels of explicit debt in most pension reformers. Figure 11 illustrates estimates of the impact of pension reform on explicit debt in Latin America, and suggests that the effect has ranged between 6 percent of GDP (Peru) to over 20 percent of GDP (Bolivia). Although, in principle, this conversion of implicit to explicit debt would not affect borrowing costs, in practice markets seem to place a greater weight on explicit debt, possibly owing to the difference in its contractual nature. In particular, Cuevas and others (2005) show that by shifting contributions away from the government and making implicit pension debt explicit, pension reforms seem to have affected negatively the reformers' perceived solvency and increased credit risk premier and the cost of debt. 
Figure 11. Selected Latin American Countries: Primary Fiscal Balance and Public Debt (with and without pension reform)

(in percent of GDP)

Argentina
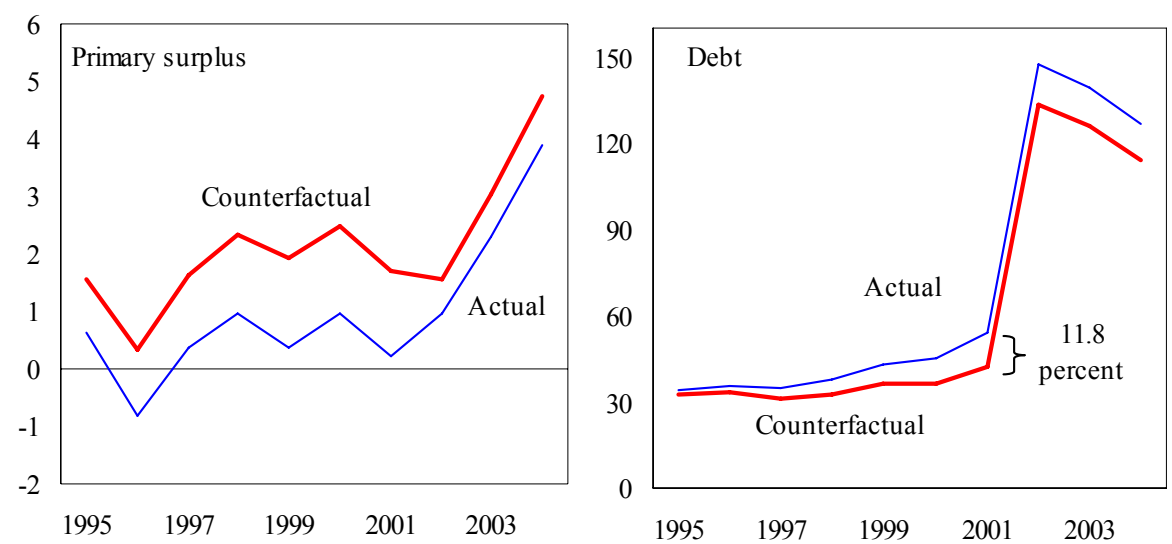

Source: Ministry of Economy and Staff Estimates

\section{Bolivia}
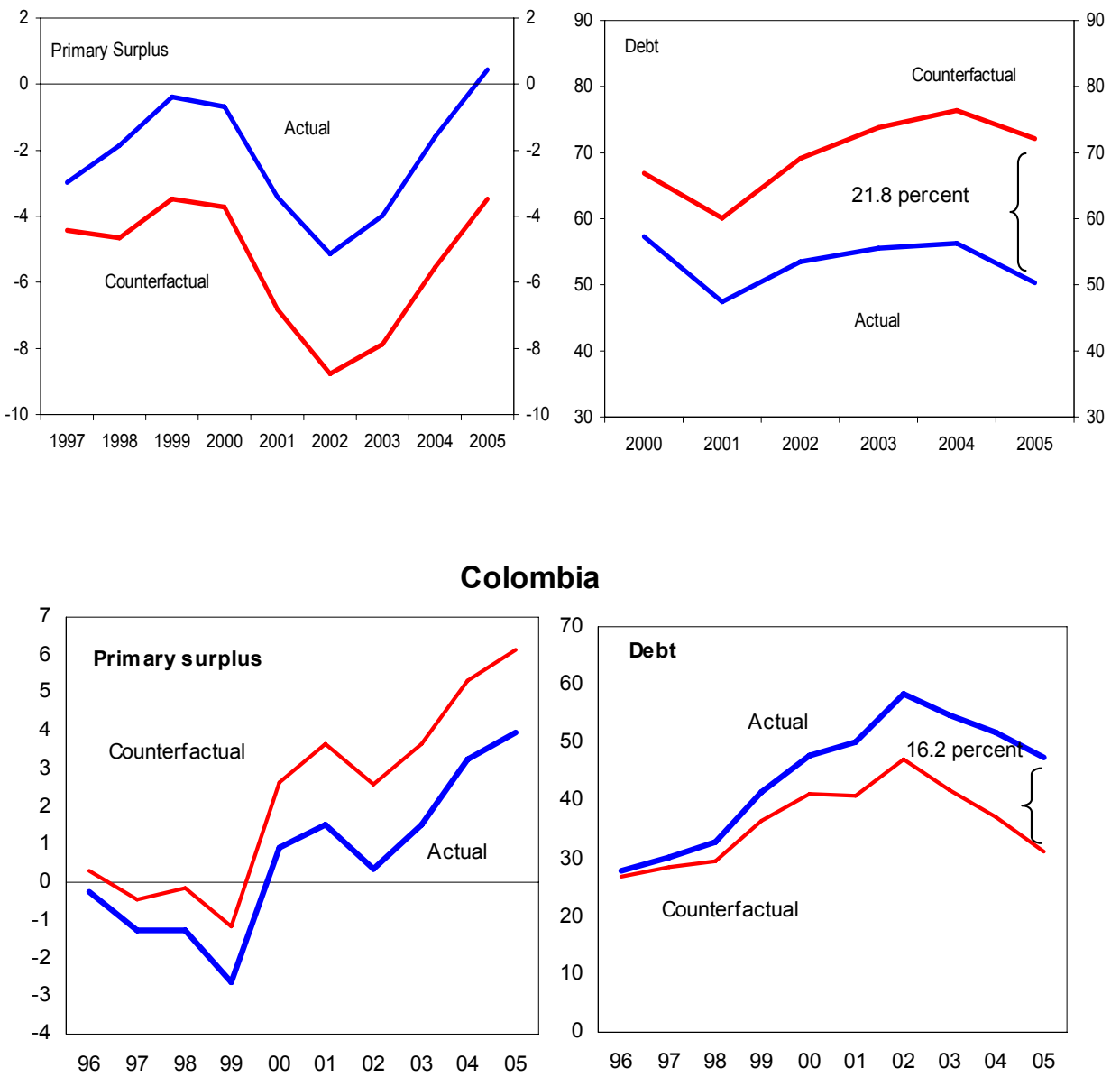

Source: Ministry of Economy and Staff Estimates 
Figure 11 (continued). Selected Latin American Countries: Primary Fiscal Balance and Public Debt (with and without pension reform)

(in percent of GDP)

\section{El Salvador}
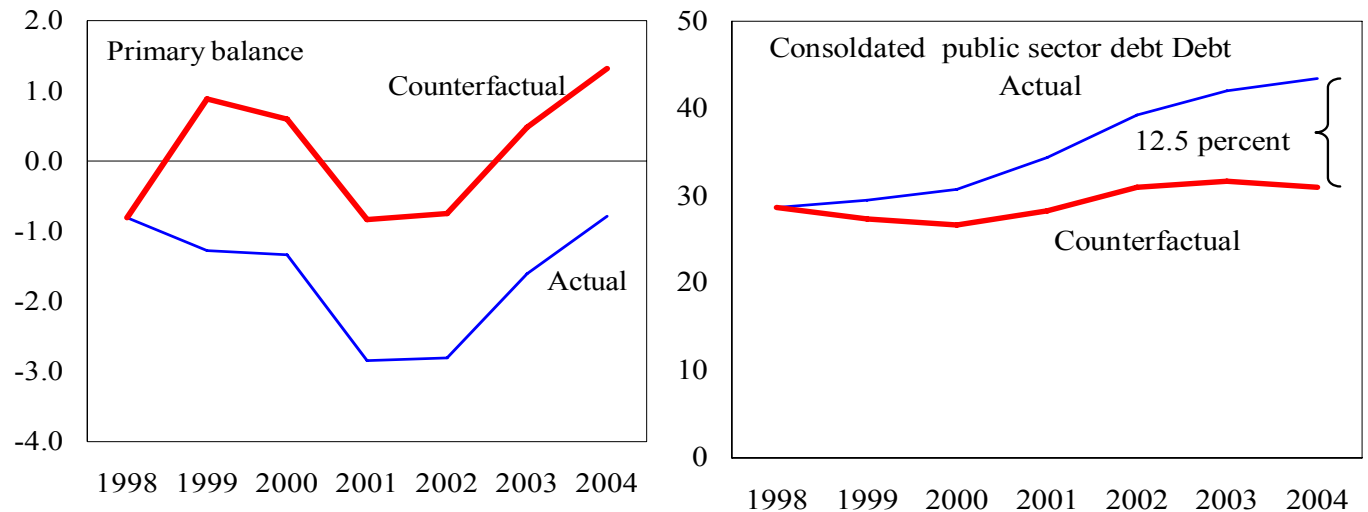

Source: Salvadorian Authorities and Staff Estimates

\section{Peru}
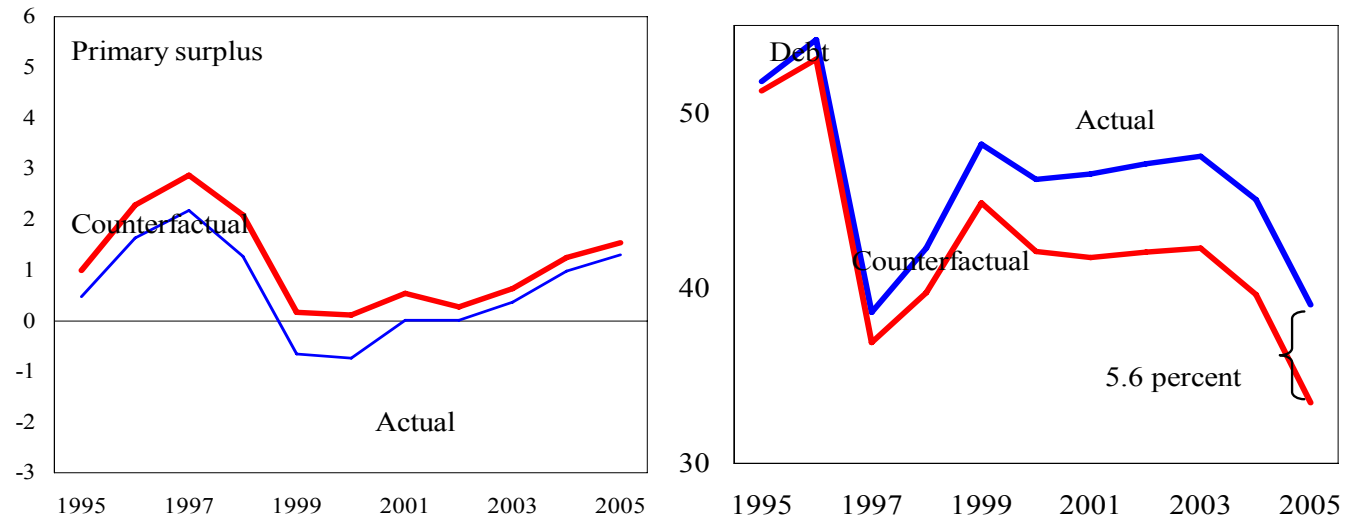

Source: Peruvian Authorities and Staff Estimates

\section{Uruguay}
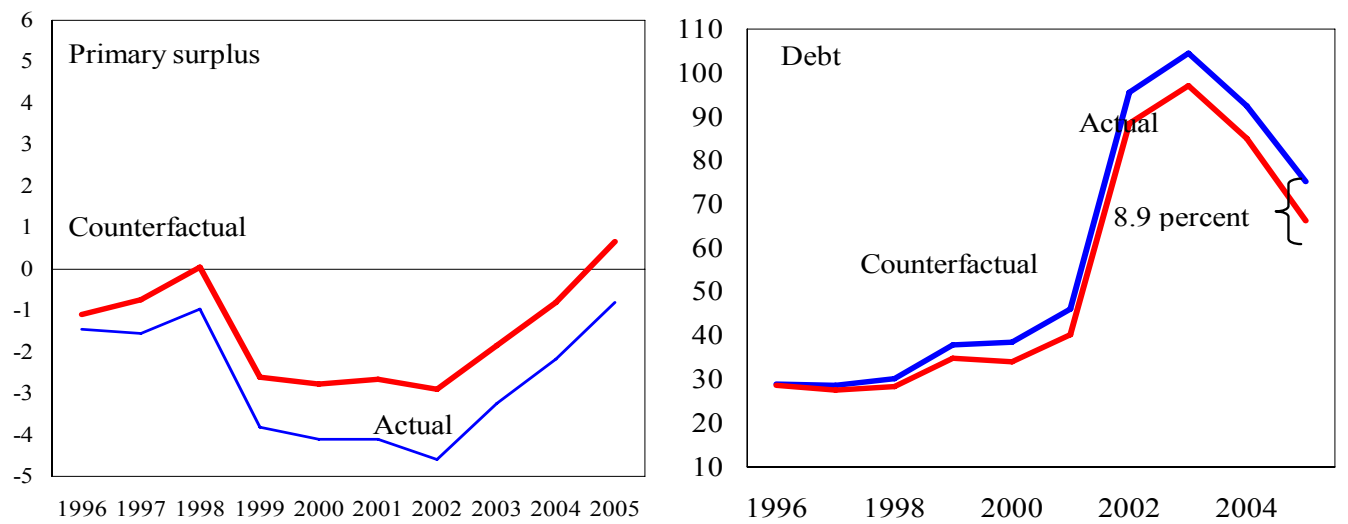

Source: Uruguayan Authorities and Staff Estimates 


\section{Conclusions ANd Policy Implications}

48. Pension reforms in most Latin American countries have had a positive effect on macroeconomic performance and capital market development. Moreover, these reforms have established a much stronger multi-pillar framework for pension systems in the region. The experience suggests a number of lessons, which are summarized below.

49. Pension reform is an ongoing process, and there are a number of areas where countries could focus on to better achieve the primary objectives of improving consumption smoothing and poverty alleviation in old age. As discussed in section II, countries could strengthen the first and third pillars, that is the safety net aspects of the system (including minimum pensions) and the complementary/voluntary savings components. The mandatory second pillar, could also be made more efficient through a number of measures, including some targeted to improve cost effectiveness and competition among private pension funds.

50. Portfolio investment limits should continue to be relaxed in a gradual manner, and this ought to be coordinated with sovereign debt management activities, as well as with legislation and regulation on capital markets. ${ }^{33}$ This would require an active coordination of debt managers with pension and securities regulators. Although the main objective of debt management activities is to minimize risk-adjusted costs of the sovereign debt, some room could be made to introduce instruments, such as indexed bonds, that fit the needs of pension funds. Also, an early adoption of legislation that facilitates the introduction of private sector securities, such as mortgage-backed securities, infrastructure bonds, private and public equity, and structured notes, would allow funds to better diversify their portfolios. ${ }^{34}$ Better legislation on corporate governance would also help funds broaden the set of corporate bonds they can safely invest in, insofar that the laws are not unduly restrictive and distinguish between bond and equity issues. ${ }^{35}$

51. Excessive concentration of pension funds' portfolios should be kept in check, not just to avoid the risk of default, but also to avoid the temptation to exploit the otherwise captive demand for government bonds from the pension funds. The latter could make governments feel less pressure to adjust the rest of the budget, while low yields could compromise the funds' returns and the replacement ratios to be obtained by future pensioners. In small

\footnotetext{
${ }^{33}$ This would also facilitate a future shift towards an internal risk-based regulatory framework for PF managers.

${ }^{34}$ The argument of early adopting of legislation also applies to instruments that are critical for the pay-out phase of pension systems, and as such are not the focus of regulatory authorities until late in the process, such as annuities (see World Bank, 2006, b).

${ }^{35}$ Rudolph and others (2006) note that some of the corporate governance requirements that are aimed at ensuring that minority shareholders are not abused by the controlling majority, could be too costly for corporates that only want to issue bonds.
} 
countries where the development of local private securities markets is less likely to be successful, this would mean opening up to investments abroad.

52. Limits on pension funds investments abroad should be relaxed gradually, and regulations on foreign assets and currency exposure should be dictated by the diversification needs and risk-adjusted return opportunities available to the pension funds - rather than FX market considerations. Opportunistic use of pension fund regulations to achieve real exchange rate objectives and reduce foreign exchange volatility should be avoided, and deepening of FX and financial markets should be fostered instead. Also, some pension fund regulations, such as industry-related minimum performance requirements, could be relaxed to reduce herding behavior. Furthermore, raising the disclosure and transparency requirements of other financial intermediaries closer to the high levels required for pension funds would remove the excessive focus on funds as drivers of most trends in asset prices, including the exchange rate.

53. While fiscal solvency was improved with most reforms, owing to the parametric changes and/or phasing out of the old PAYG systems, higher-than-expected fiscal deficits and explicit debt have constrained macroeconomic policies and at times compromised macroeconomic stability. Political economy constraints during the debate and/or implementation of reforms have reversed or made insufficient the originally envisaged parametric changes to the old PAYG regimes. This has in some cases added 2 percentage points of GDP to the transitional fiscal deficit, which if added to a likely one percent more under a cyclical down turn, could constrain fiscal policy and prompt calls for a reversal of pension reforms. Public debt has risen by more than 10 percentage points of GDP in some pension reformers, and this has raised issues of debt sustainability and increased the sovereign funding costs - since market participants seem to give more weight to explicit than implicit pension debt.

54. These fiscal issues suggest the following policy recommendations. First, building fiscal space before the pension reforms is highly desirable (GPY, 2005, World Bank, 2006). Second, authorities should develop and use actuarial models to monitor and update the impact of pension reforms on fiscal projections on a more or less continuous basis. Stresstesting these projections could also be a good crisis-prevention measure. Finally, making these projections publicly available periodically would strengthen the fiscal policy framework and facilitate the discussion of contingent policy measures before deviations become too costly. 


\section{REFERENCES}

Barr, Nicholas, 2002, “The Pension Puzzle: Prerequisites and Policy Choices in Pension Design," Economic Issues, IMF, Washington, D.C.

Baxter, Marianne and Robert King, 2001, "The Role of International Investment in a Privatized Social Security System", in Campbell and Feldstein, eds., Risk Aspects of Investment-Based Social Security Reform, NBER, The University of Chicago Press.

Borrero, Ligia, 2005, "Investment Scheme of Pension Funds in Colombia," in Pension Funds Investment, International Federation of Pension Fund Administrators, FIAP, Santiago, Chile.

Campbell, John Y., and Martin Feldstein, 2001, "Introduction”, in Campbell and Feldstein, eds., Risk Aspects of Investment-Based Social Security Reform, NBER, The University of Chicago Press.

, and Luis M. Viceira, 2002, Strategic Asset Allocation: Portfolio Choice for Long-Term Investors, Oxford University Press.

Catalan, Mario, Gregorio Impavido, and Alberto R. Musalem, 2000, “Contractual savings or Stock Market Development: Which Leads?”, Social Protection Discussion Paper Series No. 0020, August, The World Bank.

Corbo, Vittorio, and Klaus Schmidt-Hebbel, 2003, "Macroeconomic Effects of Pension Reform in Chile," in Pension Reforms: Results and Challenges, International Federation of Pension Fund Administrators, FIAP, Santiago, Chile.

Crabbe, Carolin, 2005, A Quarter Century of Pension Reform in Latin America and the Caribbean: Lessons Learned and Next Steps, IADB, Washington, D.C.

Cuevas, Alfredo, Carmenza Chahin, Henrique Maluf, Alberto Musalem, y Juan Toro, March 2006, "El Salvador-Ayuda Memoria-Estrategia para Fortalecer las Finanzas Publicas," mimeo, IMF

Cuevas, Alfredo, Maria Gonzalez, Davide Lombardo, and Arnoldo Lopez-Marmolejo, 2005, "Pension Privatization and Country Risk," mimeo, IMF, Washington, D.C.

Diamond, Peter and Salvador Valdes-Prieto, 1994, "Social Security Reforms", in Bosworth, Dornbusch and Laban, eds., The Chilean Economy: Policy Lessons and Challenges, The Brookings Institution, Washington, DC.

Echeverry, Juan Carlos, and Andres Escobar, 2005, "Uribistas, Outlaws and Deficit Targets," LatinSource, September, New York. 
Faulkner-MacDonagh, Chris, 2005, "Addressing the Long-Run Shortfalls of the Chilean Pension System”, IMF, SM/05/270.

Fletcher, Kevin, and Alfred Schipke, 2006, "Pension Reform in Central America," mimeo, IMF.

Fooladi, Iraj, and John Rumsey, "Globalization and portfolio risk over time: The role of the exchange rate," Review of Financial Economics, 15, pp. 223-236.

Garcia Cantera, Jose, Steve Faucher, Flavia Montoro and Laura Molina, 2001, "Private Pension Funds in Latin America", Equity Research: Latin America, Salomon Smith Barney, December.

Gill, Indermit, Truman Packard, and Juan Yermo, 2005, Keeping the Promise of Social Security in Latin America, The World Bank, Washington D.C.

Grandolini, Gloria, and Luis Cerda, 1998, “The 1997 Pension Reform in Mexico," Policy Research Working Paper No. 1933, The World Bank, Washington D.C.

Hausmann, Ricardo, Andres Rodriguez-Clare, and Dani Rodrik, 2005, "Towards a Strategy for Economic Growth in Uruguay," Economic and Social Study Series, IADB, Washington, D.C.

Holzmann, Robert, 1998, "Financing the Transition to Multipillar," Social Protection Discussion Paper Series, No. 9809, The World Bank.

,1999, “The World Bank Approach to Pension Reform”, Social Protection Discussion Paper Series No. 9807, September, The World Bank. , and Richard Hinz, 2005, Old Age Income Support in the $21^{\text {st }}$ Century, The World Bank, Washington, D.C.

International Monetary Fund, 2004, Global Financial Stability Report, April (Washington). , 2005, Global Financial Stability Report, September (Washington).

Jara Pinzon, Diego, Carolina Gomez Restrepo, and Andres Pardo Amezquita, 2005, “Analisis de Eficiencia de los Portafolios Obligatorios en Colombia", mimeo, Banco de la Republica, Colombia.

Mesa-Lago, Carmelo, 2000, "Estudio Comparativo de los Costos Fiscales en la Transicion de ocho Reformas de Pensiones en America Latina," Serie Financiamiento del Desarrollo, CEPAL, Santiago, Chile. 
Mathieson, Donald J., Jorge Roldos, Ramana Ramaswamy, and Anna Ilyina, 2004, "Emerging Local Securities and Derivatives Markets," World Economic and Financial Surveys, IMF, Washington, D.C.

Masias, Lorena, 2005, "Pension Fund Investment: Improvements and New Investment Alternatives", in Pension Funds Investment, International Federation of Pension Fund Administrators, FIAP, Santiago, Chile.

Patterson, Rebecca, and John Normand, 2002, "Pension Fund Reform: Anticipating FX Implications", Global Foreign Exchange Research, JP Morgan, December.

Roldos, Jorge E., 2003, "The Impact of Asset Accumulation on Capital Markets", in Pension Reforms: Results and Challenges, International Federation of Pension Fund Administrators, FIAP, Santiago, Chile.

2004, "Pension Reform, Investment Restrictions, and Capital Markets," IMF Policy Discussion Paper, PDP/04/4, IMF, Washington, D.C.

Rudolph, Heinz, Hela Cheikhrouhou, Roberto Rocha and Craig Thorburn, 2006, "Financial Dimensions of the Colombian Pension System," mimeo, The World Bank.

Samuel, Wendell, 2006, "El Salvador-Selected Issues II: Experience Under Pension Reform," IMF SM/06/241, Washington, D.C.

Schmidt-Hebbel, Klaus, 1995, "Colombia's Pension Reform: Fiscal and Macroeconomic Effects," World Bank Discussion Paper, No. 314, The World Bank, Washington, D.C.

Solnik, Bruno, 1998, "Global Asset Management," The Journal of Portfolio Management, Summer 1998.

Srinivas, P.S., Edward Whitehouse, and Juan Yermo, 2000, "Regulating Private Pension Fund' Structure, Performance, and Investments: Cross-Country Evidence," World Bank Pension Primer (Washington: World Bank).

SAFJP, 2003, "El Regimen de Capitalizacion: A 8 Años de la Reforma", Buenos Aires, Argentina.

Vargas, Hernando, and Rocio Betancourt, 2006, "Pension Fund Managers Behavior in the Foreign Exchange Market," mimeo, Banco de la Republica, Colombia.

Walker, Eduardo, 2005a, "Cobertura Cambiaria e Inversion Internacional de Portafolio: Una Perspectiva Local," mimeo, Pontificia Universidad Catolica de Chile, Santiago, Chile.

Walker, Eduardo, 2005b, "Portafolios Optimos en Sistemas de Pensiones de Contribucion Definida," mimeo, Pontificia Universidad Catolica de Chile, Santiago, Chile. 
Walker, Eduardo, and Fernando Lefort, 2000, "Pension Reform and Capital Markets: Are There Any (Hard) Links?," mimeo, Universidad Catolica de Chile.

World Bank, 2006a, "Pension Reform and the Development of Pension System: An Evaluation of World Bank Assistance", The World Bank, Washington, DC.

World Bank, 2006b, "Developing the Market for Retirement Products: The Case of Chile," The World Bank, Washington, DC.

Yermo, Juan, 2003, "Pension Reform and Capital Market Development", OECD, mimeo.

Zahler, Roberto, 2005, "Estabilidad Macroeconomica e Inversion de los Fondos de Pensiones: el caso de Chile," en Crecimiento Esquivo y Volatilidad Financiera, CEPAL, Santiago, Chile.

Zviniene, Asta, and Truman Packard, 2002, "A Simulation of Social Security Reforms in Latin America: What Has Been Gained?” mimeo, The World Bank, Washington, D.C. 